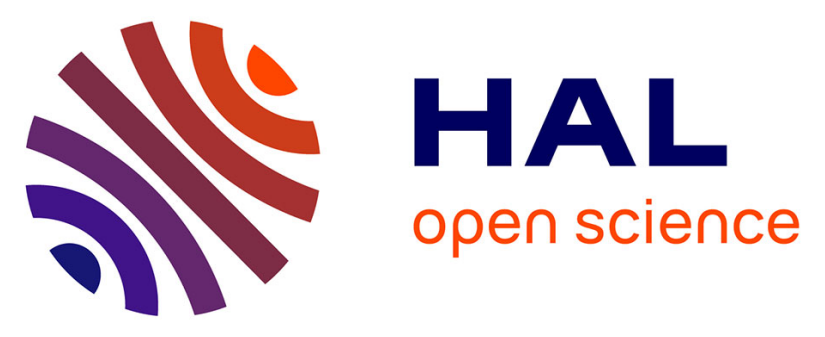

\title{
Multiple skeletal and dental pathologies in a late Miocene mesotheriid (Mammalia, Notoungulata) from the Altiplano of Bolivia: Palaeoecological inferences
}

Marcos Fernandez-Monescillo, Pierre-Olivier Antoine, Bernardino Mamani Quispe, Philippe Munch, Rubén Andradre Flores, Laurent Marivaux, Francois Pujos

\section{To cite this version:}

Marcos Fernandez-Monescillo, Pierre-Olivier Antoine, Bernardino Mamani Quispe, Philippe Munch, Rubén Andradre Flores, et al.. Multiple skeletal and dental pathologies in a late Miocene mesotheriid (Mammalia, Notoungulata) from the Altiplano of Bolivia: Palaeoecological inferences. Palaeogeography, Palaeoclimatology, Palaeoecology, 2019, 534, pp.109297. 10.1016/j.palaeo.2019.109297 . hal02263895

\section{HAL Id: hal-02263895 \\ https://hal.umontpellier.fr/hal-02263895}

Submitted on 1 Nov 2020

HAL is a multi-disciplinary open access archive for the deposit and dissemination of scientific research documents, whether they are published or not. The documents may come from teaching and research institutions in France or abroad, or from public or private research centers.
L'archive ouverte pluridisciplinaire HAL, est destinée au dépôt et à la diffusion de documents scientifiques de niveau recherche, publiés ou non, émanant des établissements d'enseignement et de recherche français ou étrangers, des laboratoires publics ou privés. 
1 Multiple skeletal and dental palaeopathologies in a mesotheriid individual

2 (Mammalia, Notoungulata) and palaeoecological inferences in the upper Miocene

3 of the Bolivian Altiplano.

4

5 Marcos Fernández-Monescillo ${ }^{\mathrm{a},}{ }^{*}$,Pierre-Olivier Antoine ${ }^{\mathrm{b}}$, Bernardino Mamani Quispe ${ }^{\mathrm{c}}$, 6 Philippe Münch ${ }^{\mathrm{d}}$, Rubén Andrade Flores ${ }^{\mathrm{c}}$,Laurent Marivaux ${ }^{\mathrm{b}}$, François Pujos ${ }^{\mathrm{a}}$ 7

${ }^{a}$ Instituto Argentino de Nivología, Glaciología y Ciencias Ambientales (IANIGLA),

9 CCT-CONICET-Mendoza, Avda. Ruíz Leal s/n, Parque Gral. San Martín, 5500

10 Mendoza, Argentina

11 b Institut des Sciences de l'Evolution, cc64, Université de Montpellier, CNRS, IRD,

12 EPHE, F-34095 Montpellier, France

$13{ }^{\mathrm{c}}$ Departamento de Paleontología, Museo Nacional de Historia Natural, Calle $26 \mathrm{~s} / \mathrm{n}$, Cota 14 Cota, La Paz, Estado Plurinacional de Bolivia

$15{ }^{\mathrm{d}}$ Géosciences Montpellier, Université de Montpellier, CNRS, F-34095 Montpellier,

16 France

17

$18{ }^{*}$ Corresponding author e-mail address : mfernandezmonescillo@gmail.com (M.

19 Fernández-Monescillo)

20

21 Abstract

22 We report here the first case of bilateral mandibular hypodontia for a notoungulate,

23 further associated with exostosis on various limb bones. We describe a partial skeleton

24 of a palaeopathological individual of the notoungulate mesotheriid Plesiotypotherium

25 achirense, from the Upper Miocene site of Achiri, Bolivian Altiplano. The main 
26 pathology is hypodontia of two first molars on both sides of the jaw. Other 27 craniomandibular affliction, likely related to the latter pathology, are a striking 28 overgrowth of two first upper molars on both sides and the anomalous development of masticatory muscle insertions (m. masseter, pterygoideus medialis, temporalis, and temporalis pars profundis). The pathological sequence of the masticatory apparatus was reconstructed in this individual according to distinctive wear of ever-growing crowns of two first upper molars, and the unequal lower alveoli reabsorption. Additional pathologies are exostoses observed on several articular surfaces of limb bones, from the scapula to distal phalanges. They likely decreased the range of movements during locomotion of this individual. Given its multiple pathologies, we might have expected this abnormal individual to be a potential easy prey. However, the long-time survival of this animal suggests a low predatory pressure in this area at that time, a hypothesis which is consistent with the virtual absence of flesh-eating vertebrates in the Achiri fossil record.

Key words: South America, late Neogene, Typotheria, Plesiotypotherium, palaeopathology, hypodontia, exostosis.

\section{Introduction}

Notoungulata are among the most successful and diversified South American mammalian clades in the Cenozoic, with a late Palaeocene-Holocene range (e.g., Simpson, 1948; McKenna and Bell 1997; Croft, 1999). Within species-rich rodent-like notoungulates (Typotheria; Reguero and Prevosti, 2010), Mesotheriidae include Trachytheriinae (Oligocene; Billet et al., 2008) and Mesotheriinae (MiocenePleistocene; Paz et al., 2011). In the Bolivian Altiplano, the Upper Miocene locality of Achiri (Pacajes Province, La Paz Department) was first reported by Hoffstetter et al. (1972). The most common taxon in Achiri is the mesotheriine Plesiotypotherium 
51 achirense, with ca. $64 \%$ of the mammalian fossil specimens recovered (45 out of 70 )

52 (Fernández García, 2018). The excavations carried out in the Achiri area during the last decade have allowed for recovering cranial, mandibular, and postcranial remains of $P$. achirense, including a partial skeleton of a striking individual displaying multiple dental and skeletal pathologies (MNHN-Bol-V 12617). These palaeopathologies are mainly observed in the masticatory apparatus and in the postcranial skeleton. Pathologies were so far virtually undocumented among Notoungulata, with the noticeable exceptions of a few dental defects (enamel hypoplasia; Toxodon sp.; Braun et al., 2014), and postcranial exostoses (Toxodon platensis; Guérin and Faure, 2013) in Pleistocene toxodontids. To our knowledge, the individual MNHN-Bol-V 12617 is the first case of multiple osteodental pathologies formally described among Mesotheriidae. Noticeably, an individual of the late Oligocene mesotheriid Trachytherus alloxus with multiple broken limb bones subsequently healed has been recently reported (Croft, 2016), but it has not been described yet. In this paper we (1) describe the pathologies of this individual of $P$. achirense with respect to numerous asymptomatic specimens from the same taxon and locality, and (2) provide hypothetical palaeobiological inferences based on the longlasting survival of this abnormal mesotheriine individual, and the scarce flesh-eating taxa evidence at Achiri at this time.

\section{Material and methods}

\subsection{Material}

\subsubsection{Institutional abbreviations}

MNHN-Bol, Museo Nacional de Historia Natural, La Paz, Bolivia; MNHN, Muséum national d'Histoire naturelle, Paris, France.

\subsubsection{Plesiotypotherium achirense specimens}


The pathological specimen MNHN-Bol-V 12617 of Plesiotypotherium achirense was unearthed at the top of the Cerro Pisakeri (Fig. 1A-B). All asymptomatic specimens used for comparison come from the same geological unit (Mauri Formation [Fm.], Unit IV), also in the Achiri area (Fig. 1B).

\subsubsection{Systematic palaeontology}

Order Notoungulata Roth 1903

Suborden Typotheria Zittel 1893

Family Mesotheriidae Alston 1876

Subfamily Mesotheriinae Alston 1876

Genus Plesiotypotherium Villarroel 1974

Plesiotypotherium achirense Villarroel 1974

(Figs. 2-5)

\subsubsection{Measurements}

We have used a digital calliper of $150 \mathrm{~mm}$ (precision $\pm 0.1 \mathrm{~mm}$ ). Measurement abbreviations (craniomandibular, dental, and postcranial) and the summary of the measurements of the study specimen and other $P$. achirense specimens appears in Supplementary Material 1.

\subsubsection{X-ray tomography and 3D surface rendering}

The skull and mandible of the pathological individual of $P$. achirense (MNHNBol-V 12617) and other asymptomatic cranial specimen (MNHN-Bol-V 8507) and mandible (MNHN-Bol-V 12669) were scanned in the MEDICENTRO clinic of La Paz, Bolivia, using a Phillips MX 8000 clinical CT Scanner (140Kv and $300 \mathrm{~mA} ; 0.26 \mathrm{~mm}$ pixel size and $0.75 \mathrm{~mm}$ interslice). The digital surfaces (skull and mandible) were extracted using AVIZO 10.0 (FEI Visualization Sciences Group). The skull and mandible were generated by thresholding tool, while the dental reconstruction was made 
101

102

103

104

105

106

107

108

109

110

111

112

113

114

115

116

117

118

119

120

121

122

123

124

125

manually slice by slice. Finally, the 3D surfaces were generated using unconstrained smoothing option with a value of ca. 3.5-4.

\subsubsection{Anatomical description}

The osteological terms follow the terminology of the Nomina Anatomica Veterinaria (Wible et al., 2005). As for orientation, we used the terms: anterior, posterior (occipital), dorsal, medial, and lateral (skull and mandible); mesial, distal, lingual, and labial (in teeth); medial (sagittal plane), lateral, cranial (dorsal in the manus and pes), caudal (palmar in the manus and plantar in the pes), proximal, and distal (appendicular skeleton). The pelvis and Mt I had not been previously reported for this taxon.

\subsubsection{Dating}

The fossil-yielding sedimentary series at Cerro Pisakeri includes five volcanic tuffs. We dated two tuffs immediately bracketing the pathological specimen: sample ACH-TUF3 and sample ACH-TUF4, which are located five metres beneath and ten metres above the MNHN-Bol-V 12617 specimen, respectively. We performed stepheating ${ }^{40} \mathrm{Ar} /{ }^{39} \mathrm{Ar}$ experiments on feldspar micro-populations (detailed methodology in online Supplementary Material 2). For the sample ACH-TUF3, we obtained a plateau age of $10.35 \pm 0.07 \mathrm{Ma}$, corresponding to $57.4 \%$ of ${ }^{39} \mathrm{Ar}$ released (five steps; Supplementary Material 3). We also calculated for all steps an inverse isochron age of $10.42 \pm 0.09 \mathrm{Ma}$ with a MSWD $=4.55$ and an initial ${ }^{40} \mathrm{Ar} /{ }^{36} \mathrm{Ar}$ ratio of $299.9 \pm 2.3$ (Supplementary Material 4), indicating that the trapped ${ }^{40} \mathrm{Ar} /{ }^{36} \mathrm{Ar}$ is indistinguishable from the atmospheric ${ }^{40} \mathrm{Ar} /{ }^{36} \mathrm{Ar}$. We retained the inverse isochron age at $10.42 \pm 0.09$ Ma for the tuff below the MNHN-Bol-V 12617 specimen. For the sample ACH-TUF4, we obtained a plateau age of $9.42 \pm 0.1$ Ma corresponding to $99.39 \%$ of ${ }^{39} \mathrm{Ar}$ released (Supplementary Material 5). These ${ }^{40} \mathrm{Ar} /{ }^{39} \mathrm{Ar}$ datings confirm that the fossil assemblage from the Cerro Pisakeri, including the pathological specimen, is Upper Miocene in age 
126 (late Mayoan-early Chasicoan South American Land Mammal ages [SALMA], based 127 on Gradstein et al., 2012).

128

\subsection{Description of the pathologies}

\subsubsection{Pathological descriptions}

We use the term hypodontia considered as the absence of teeth (less than six teeth expect the third molars, primary or definitive dentition; Pemberton et al. 2005), and related absent of teeth development (Al-Ani et al. 2017). The taxon P. achirense, as member of the Mesotheriinae subfamily is characterized by hypselodontia (evergrowing teeth; Gomes Rodrigues et al. 2017), therefore the teeth development is increased during the life of the animal.

The term exostosis is used to refer to any outgrowth of a bone (bony spur) from the cortical surface and is a more general term than the entity of osteochondroma, or osseocartilaginous exostosis (Khurana 2008).

\subsubsection{Skull and upper teeth}

The skull of the pathological individual (MNHN-Bol-V 12617) does not show any particular osteological deformation in its dorsal, anterior and occipital aspects (Fig.

1431 Supplementary Material 1 A-D, Fig. 2A-D). In lateral views (Fig.1 Supplementary Material 1 C-D), overgrown M1s and M2s stand out on both sides. The M1-M2s are not

145 pathological teeth per se (no unusual outline or cusp Bauplan), but unworn hypselodont

146 teeth instead, characterised by a striking overgrowth due to the absence of occlusion 147 with their missing lower counterparts (hypodonty of both $\mathrm{m} 1$ and $\mathrm{m} 2$; Fig.1 148 Supplementary Material 1 C-D, Fig. 2A-D). The CT-Scan M1-M2 reconstruction 149 discard any post-dead teeth ejection from the alveolus (Fig. 2 A-D). The M1s further 150 present an anomalous wear, with oblique mesial wear at the mesial border or protoloph 
151 (not at the same occlusal plane than the crista 2-crochet or metaloph; Fig. 2A-D). The

152 M2s show also an oblique wear at the distal border, affecting the metaloph and crista 2-

153 crochet (not as the same plane than the protoloph; Fig. 2A-D). The M3s have developed

154 a generic wear (Fig. 2A-D) with respect to specimens from other individuals (i.e.

155 MNHN-Bol-V 8507; Fig. 2E-H).

156

\subsubsection{Mandible and lower teeth}

157

The mandible is the main pathological element of MNHN-Bol-V 12617 (Fig. 2

158

Supplementary Material 1 A-E) with respect to normal individuals (i.e. MNHN-Bol-V

12669, Fig. 2 Supplementary Material 1 F-G). The identified pathologies are: (1) a

bilateral hypodontia of m1-m2 (Fig. 3A-D); (2) anomalous bone structures in the ventrolateral and ventromedial border of the right mandibular ramus (Fig. 2 process (Fig. 2 Supplementary Material 1 B); and (4) an anomalous and rounded overgrowth of the enamel of the right il (Fig. 2 Supplementary Material 1 D). The alveoli of left and right $\mathrm{m} 1 \mathrm{~s}$ are closed, whereas those of $\mathrm{m} 2 \mathrm{~s}$ are still open but shows initial alveolar bone resorption (Fig. 3 C-D). Compared with other referred specimens resorption, which affects the ventrodorsal height of the right mandibular ramus (Fig. 2 A-D). The p4 shows an oblique (distoventral orientation) wear, finishing in a remarkable mesial tip (Fig. 3A-D), absent in other assigned specimens (Fig. 3E-H). The m3 shows a normal occlusal wear, except for a slight rostroventral orientation (Fig. 3AB), lacking in other individuals (Fig. 3E-F).

\subsubsection{Postcranial skeleton (Axial and appendicular)}

175 vertebra, both scapulae, both radii, left ulna, left Mc IV, right Mc V, left scaphoid (Fig. 3 
176 Supplementary Material 1), fused sacrum and pelvis, left Mt I-III, V, left navicular, left

177 cuboids and left ectocuneiform (Fig.4 Supplementary Material 1). On the right scapula,

178 the suprahamatus process (metacromion; see Fernández-Monescillo et al. 2018) shows

179 an ossified callus, which could correspond to a fracture subsequently healed (Fig. 4A).

180 Most postcranial remains available show slight exostosis in their articular surfaces: (1)

181 the coronoid process and glenoid cavity of the scapula; (2) the lateral and medial

182 borders of the caput radii (radius head) (Fig. 4B-C); (3) both lateral and medial sides of

183 the proximal articular surface of Mc IV, Mc V, Mt II, Mt III and Mt V (Fig. 4E); (4) the

184 coronoid process and anconeus process edges on the fragmentary left ulna (Fig. 4D); (5)

185 the articular borders of carpals (scaphoid) and tarsals (navicular, ectocuneiform, and

186 cuboids); and (6) also the surrounded external articular borders in the proximal

187 epiphysis of the first phalanges (not second or third phalanges) of manus and pes (Fig. $1884 \mathrm{~F})$.

189

$190 \quad 3 . \quad$ Discussion

191

\subsection{Masticatory apparatus pathology}

192

In humans, hypodontia is congenital and it seems to have a genetic component.

193 Although the genetic origin of this anomaly remains unknown, polymorphism in 5,

194 flanking region of the PAX9 gene (Peres et al., 2005) and AXIN2 (Mostowska et al.,

195 2006) have been associated with non-syndromic hypodontia in humans (Pemberton et

196 al., 2005, Al Ani et al. 2017). Hypodontia is considered as the most common dental

197 anomaly in any human populations (e.g., Pemberton et al., 2005; Altug-Atac and

198 Erdem, 2007; Al-Abdallah, 2015). Hypodontia affects different teeth or dental regions,

199 and this affliction differs according to the ethnic groups of humans: second mandibular

200 premolars in North American children (Clayton, 1956), lateral maxillary incisors in 
201 Saudi Arabian children (Al-Emran, 1990), second maxillary premolar in European

202

203

204

205

206

207

208

209

210

211

212

213

214

215

216

217

218

219

220

221

222

223

224

225 children (Grahnén, 1956), or lateral maxillary incisors followed by premolars in Turkish population (Altug-Atac and Erdem, 2007). Lavelle and Moore (1973) indicated primarily molar region affliction for humans. In human populations, the hypodontia occurs more often bilaterally than unilaterally (Silverman and Ackerman, 1979; Polder et al., 2004) or with almost similar percentage affliction (Al-Abdallah, 2015), and furthermore it is more common in the mandible (Wisth et al., 1974). Contrastingly, hypodontia affects mostly premolars and molars in other mammals (e.g., Cuesta RuízColmenares et al., 2004; Dacre, 2006). This dental pathology has been documented in domestic mammals like cats (Mestrinho et al., 2018), dogs (Pavlica et al., 2001) and equids (Dixon et al., 1999; Ramzan, 2001; Dacre, 2006; Easley, 2006).

In wild animals, hypodontia has been deeply documented in: (1) artiodactyls such as bighorn sheep (Lyman, 2010), Spanish wild goats (Vigal and Machordom, 1985; Gómez-Olivencia et al., 2011), mountain goat (Cowan and McCrory, 1970), wild Japanese serow (Natsume et al., 2005); and (2) primates, notably in Cercopithecoidea (Lavelle and Moore, 1973) and especially in colobines (Jablonski, 1992). By contrast, hypodontia has so far remained poorly documented in extinct mammals, with the exception of hypodontia reported on P4 of a lophiodontid perissodactyl from the Eocene of Spain (Cuesta Ruíz-Colmenares et al., 2004).

Hypodontia or dental affliction negatively impacts the masticatory function and global masticatory apparatus, as it can disrupt dental occlusion and constrain chewing movements as a result (Dixon and Dacre, 2005; Brown et al., 2008; Ardila and Montoya, 2009; Ali et al. 2014). It is documented in MNHN-Bol-V 12617 through the osteological anomaly noticed on the mandibular ramus, affecting the concerned muscular insertion. Indeed, the anomalous bone structure located on the ventrolateral 
226

227

228

229

230

231

232

233

234

235

236

237

238

239

240

241 242 Ani et al. 2017). Over 300 genes are expressed and involved in tooth morphogenesis

243 (Kapadia et al. 2007; Küchler et al. 2013; Alves-Ferreira et al. 2014). In the case of

244

245

and ventromedial borders of the mandible likely impacted the insertion of the $\mathrm{m}$. masseter and pterygoideus medialis, respectively (Fernández García, 2018). The rostrocaudal elongation of the coronoid process would also have affected the insertion of the m. temporalis laterally, and of the m. temporalis pars profundis medially (Fernández García, 2018). Accordingly, an anomalous chewing cycle can be inferred for this mesotheriid specimen. Given these observations, it may be expected that hypodontia pathology would have affected more severely the masticatory apparatus of taxa with hypselodont (i.e., mesotheriines) than hypsodont or brachydont dentition, due to extreme overgrowth of non-opposed counterparts.

The dental formula of adult mesotheriines is 1023/2013 (Francis, 1965; Thenius, 1989). The M3s erupt faster than permanent upper premolars (Gomes Rodrigues et al., 2017). The presence of DP2, DP3 and DP4 is confirmed by several authors (e.g., Kraglievich, 1934; Francis, 1965; Gomes Rodrigues et al., 2017). In mesotheriids, distinct patterns of dental development are documented in hypsodont trachytheriines and hypselodont mesotheriines (Gomes Rodrigues et al., 2017). Several studies have been focussed to identified the specific genes involved into the tooth development (Alhypselodont (ever-growing) teeth observed in mousses the continuous tooth renewal capacity relies on epithelial and mesenchymal stem cells (Renvois and Michon 2014). The term "crown-to-root transition" designated for hypselodont teeth, is fundamental to keep the balance between the suppling cells of the crown and that of the root to holding the tooth in place (Renvois and Michon 2014). In murine molars (hypselodont) is evidence loss of epithelial Notch and mesenchymal FGF (fibroblast growth factor) signal, helping in the continuous growth of the molar crown (Harada et al. 2002, 
251 Yokohama-Tamaki et al. 2008).

252 MNHN-Bol-V 12617 exhibits a complete adult upper and lower dental formula

253 (without deciduous teeth), except for the absence of m1-m2. This dental anomaly is 254 identified as a bilateral hypodontia that occurred with already definitive molars erupted. The absence of osseous displacement or bridging callous presence of the mandibular ramus would discard an osseous fracture event. Also, agenesis (no teeth formation) of $\mathrm{m} 1-\mathrm{m} 2$ is discarded by effectively wear trilobed pattern of upper molars counterparts. In addition, the alveolus of $\mathrm{m} 2$ still open, the smooth aspects of the surface of the surrounded areas of $\mathrm{m} 1$ and $\mathrm{m} 2$ alveoli, and the absence of any osseous tissue swelling, and its bilateral and symmetrical aspects most likely discard infection as a potential cause for this pathology. Thus, would tentatively relate it with genetical factors provably affecting the hypselodont epithelial stem cells or the molecular regulation. According to the distinctive wear pattern of the crowns of hypselodont M1-M2, his distinct occlusal level reached, and the unequal alveolar reabsorption of $\mathrm{m} 1-\mathrm{m} 2$, the pathology of the masticatory apparatus can be sequentially reconstructed as follows:

(1) Initially, the upper and lower teeth occlusion would be non-pathological, this is inferred according to the trilobed occlusal pattern of the upper molars (M1-M3), with no closed crown (Fig. 5A);

(2) Posteriorly, mandibular hypodontia likely appeared first for $\mathrm{m} 1$. This is suggested taking into account the major M1 overgrowth (crista 2-crochet and metaloph)

271 in comparison to M2, and a closed alveolus of the m1 (right and left; Fig. 5B);

(3) Finally, hypodontia would have occurred for m2, a last step inferred from the major crown wear of the protoloph and medial crista 2-crochet on M2 (compared to M1), and the maintain of an open alveolus of the $\mathrm{m} 2$ (in early stages of alveolar reabsorption) (Fig. 5C). 
According to the pathological stages of the occlusal dental surfaces, it can be

277 inferred that $\mathrm{P} 3, \mathrm{P} 4$, and the protoloph of M1 were partially worn by $\mathrm{p} 4$, and that the

278 crista 2-crochet and entoloph of M2-M3 were eroded by m3. This growing sequence is

279 likely to offer key information for morphofunctional studies of the masticatory 280 apparatus in mesotheriids. On MNHN-Bol-V 12617, there is no evidence of enamel 281 hypoplasia that is usually recognised as a sign of starvation or feeding stresses in 282 mammals (Mead, 1999). Therefore, a long-time starvation for this individual is not suggested, although the craniomandibular pathologies may have limited the food intake. Indeed, m1-m2 hypodontia (during life time) associated with the extreme M1-M2 overgrowth have involved constrained/abnormal chewing movements, as highlighted by the anomalous muscular insertions of some maxillomandibular muscles, which have probably affected a normal feeding supply.

\subsection{Postcranial pathologies}

In mammals, postcranial pathologies identified as exostoses are identified in:

(1) modern wild animals such as bovids (e.g., Tragelaphus sp., Addax nasomaculatus, Bison bison, Oryx gazella; Greer et al., 1977), cervids (e.g., Odocoileus virginianus, Cervus sp.; Greer et al., 1977) felids (e.g., Panthera leo; Greer et al., 1977), canids (Canis lupus; Greer et al., 1977), mustelids (e.g., Gulo gulo; Greer et al., 1977, or Lutra lutra; Prummel, 1987), ailurids (Ailurus fulgens; Lynch et al., 2002), and also ursids (Ursus arctos; Bartosiewicz, 2002);

(2) modern domesticated animals such as cats (Pool and Carrig, 1972), dogs (Dingwall et al., 1970; Silver et al., 2001), and horses (Bertoni et al., 2012);

(3) and extinct animals such as cave bears (Torres et al., 2005), machairodontine felid carnivorans (Salesa et al., 2014), and South-American endemic mammals like 
300 ground sloths (McDonald, 1989; Pujos et al., 2016), glyptodonts (Glyptodon sp.;

301 Gillette and Ray, 1981), and notoungulates (Toxodon platensis; Guérin and Faure, 302 2013).

When severe, an exostosis on a bone articulation decreases the range of

304 movements and causes pain (Bertoni et al., 2012; Gavanier and Blum, 2017). The 305 pathological condition of exostosis observed on MNHN-Bol-V 12617 is categorised as 306 level 2 (i.e., "showing a minor irregular bulging of bone") according to the classification of Stilton et al. (2016). Although slight, the numerous exostoses observed on the articular surfaces of the available postcranial elements of MNHN-Bol-V 12617 indicate that this pathological individual of Plesiotypotherium achirense may have presented such symptoms.

\subsection{Palaeoecological inferences}

The vertebrate fauna from the Mauri $6 \mathrm{Fm}$. is dominated by Plesiotypotherium, considered as a "guide fossil" for upper Miocene deposits of the Bolivian Altiplano

314 (Marshall et al., 1983). In Achiri, P. achirense is the dominant species with a prevalence of ca. 64\%, among other notoungulates (Toxodontidae and Hegetotheriidae), xenarthrans (sloths and cingulates), and rodents. coeval to the Cerro Pisakeri assemblage (ca. $10.66 \pm 0.06 \mathrm{Ma}$; Gregory-Wodzicki, 2002). They indicate mean annual temperatures (MAT) of $21.5^{\circ} \mathrm{C}$, mean annual precipitations of $550 \pm 180 \mathrm{~mm}$, and mean growing season precipitations of $580 \pm 160$

$321 \mathrm{~mm}$ (Gregory-Wodzicki, 2002). Moreover, these palaeo-floras allow estimating a 322 palaeo-elevation of $1,160 \pm 600 \mathrm{~m}$, which is almost $2,800 \mathrm{~m}$ lower than the current 323 elevation (Gregory-Wodzicki, 2002), and consistent with estimates of 1,200 $\pm 1,000 \mathrm{~m}$ 324 (Garzione et al., 2008) and 1,400 $\pm 400 \mathrm{~m}$ (Lamb, 2016) determined from isotopic 
325 palaeo-elevation proxies. The upper Miocene palaeo-floras of the northern Altiplano and from other locations in the Central Andes suggest that a large portion of this region

327 was covered by subtropical-dry forests under a subtropical-dry climate at moderate 328 elevations (Gregory-Wodzicki, 2002 and references therein). Such palaeo-ecological 329 conditions may have favoured the large development of mesotheriine notoungulates in 330 the northern Altiplano during Upper Miocene times, more specifically at ca. 10 Ma.

331 These conditions drastically changed during the Pliocene, with a noticeable cooling 332 (MAT 8-9 ${ }^{\circ}$ C; Gregory-Wodzicki et al., 1998) associated with a substantial rise of that 333 region, up to modern height at ca. 4,000 m above sea level (Garzione et al., 2008; Lamb, 334 2016). These drastic abiotic changes affected mammalian communities of the northern 335 Altiplano as demonstrated by the major faunal turnover recorded around the Miocene336 Pliocene transition: mesotheriines (primarily Plesiotypotherium) were dominant during 337 the upper Miocene whereas ground sloths became dominant during the Pliocene 338 (Marshall et al., 1983; Pujos et al., 2016).

The only flesh-eating taxon attested in the Achiri assemblage is the 340 sparassodontan metatherian Borhyaenidium altiplanicus, documented by a single specimen (MNHN-Bol-V 011889=ACH-0243, holotype; Villarroel and Marshall, 1983).

342 In addition, there is no record either for prey birds, snakes, or crocodylians at Achiri 343 (Villarroel and Marshall, 1983). Moreover, no predation mark has been identified on the 344 available bone sample (old and new collects). Predators are known to mainly hunt 345 substandard individuals (Temple, 1987; Genovart et al., 2010), as would be the case for 346 the Plesiotypotherium achirense individual (MNHN-Bol-V 12617). According to that, 347 due to its numerous pathologies of the chewing-cycle abnormalities, mostly evidenced 348 in mandibular muscles insertion and extreme M1-M2 overgrowth, the normal feeding 349 intake would be affected. Also, the postcranial pathologies (exostoses) would suggest a 
350

351

352

353

restricted appendicular movement, that would identify as preferential prey for predators. The inferred long-termed multiple pathologies would have increased the probability for this mesotheriine of being hunted. Strikingly, no predation evidence is visible in this individual, and no other precise cause can be evoked for its death. This, together with the almost inexistent presence of flesh-eating taxa at Achiri at this time would suggest a very low predation pressure, thus confirming other observations in pre-GABI Cenozoic stages of South America with respect to other continental regions (e.g., Holarctic or Australian regions; Croft, 2006; Croft et al., 2018; Prevosti and Forasiepi, 2018).

\section{Conclusions}

The palaeo-ecological conditions inferred at the late Mayoan-early Chasicoan SALMAs (10 Ma) at the Bolivian Altiplane clearly favoured the dominant faunas (Plesiotypotherium, Mesotheriinae), while dramatical climatic change at the MioPliocene transition identified the major faunal turnover with the major prevalence of ground sloths during the Pliocene.

The surprising encounter of the study sample MNHN-Bol-V 12617 of $P$. achirense, characterized by numerous and long-termed multiple paleopathologies (craniomandibular, dental, and postcranial) would identify as potential prey with increased chances to be hunted. This, together with the almost inexistent presence of flesh-eating taxa at Achiri at this time would suggest and confirming other observations in other Cenozoic stages of South America compared with other Australian or Holarctic regions.

Acknowledgments: We thank all the team members (M. A. Abello, S. Adnet, G. Billet, and M. B. Prámparo) who participated to the 2010-2015 field campaigns in Achiri. We 
375 thank the staff of the MEDICENTRO clinic in La Paz (Bolivia) for providing access to 376 CT Scan facilities. We warmly thank to Juan Esteban Rodriguez 377 (http://juanestebanartwork.com/) because his exceptional reconstruction of 378 Plesiotypotherium achirense. We are indebted to the people and local authorities from 379 Achiri for facilitating our fieldwork during the 2010-2018 campaigns. We thank A. 380 Iemmolo for his technical support during ${ }^{40} \mathrm{Ar} /{ }^{39} \mathrm{Ar}$ analyses. This project was made 381 possible according to the cooperation agreement ( $\left.\mathrm{N}^{\circ} 864 / 2014\right)$ between the MNHN382 Bol (Bolivia), the ISE-M (France), and the CONICET (Argentina). This work was 383 financially supported by the ECOS-FonCyT program (A14U01), the National 384 Geographic Society (NGS 9971-16), and by the "Investissements d'Avenir" grant managed by the "Agence Nationale de la Recherche" (CEBA, ANR-10-LABX_0025_ $01)$.

\section{References}

Al-Abdallah, M., 2015. Prevalence and Gender Distribution of Permanent Tooth Agenesis among Jordanian Dental Patients: A Cross-Sectional Survey. Jordan Medical Journal 49:241-251.

Al-Ani, A.H., Antoun, J.S., Thomson, W,T., Merriman, T,R; Farella, M., 2017. Hypodontia: An Update on Its Etiology, Classification, and Clinical Management. BioMed Research International. 9378325, 1-9.

Al-Emran, S., 1990. Prevalence of hypodontia and developmental malformation of permanent teeth in Saudi Arabian schoolchildren. British Journal of Orthodontics 17:115-118. Syndrome (MPDS). Journal of the Pakistan Dental Association 23: 15-18. 
400 Alston, E.R., 1876. On the classification of the Order Glires. Proceedings of The $401 \quad$ Zoological Society 44:61-98.

402 Altug-Atac, A.T., D. Erdem., 2007. Prevalence and distribution of dental anomalies in 403 orthodontic patients. American Journal of Orthodontics and Dentofacial $404 \quad$ Orthopedics 131:510-514.

405 Alves-Ferreira, M; Pinho, T., Sousa, A; Sequeiros, J; Lemos, C., Alonso, I., 2014.

406 Indentification of genetic risk factors formaxillary lateral incisor agenesis. $407 \quad$ Journal of Dental Research 93: 452-458.

408 Ardila, C.M., L. Montoya., 2009. Desórdenes bucales equinos. Revista de Salud Animal $409 \quad 31: 143-151$.

410 Bartosiewicz, L. 2002., Pathological Lesions on Prehistoric Animal Remains from 411 Soutwest Asia; pp. 320-360 in H. Buitenhuis, M. Mashkour, A. M. Choyke, and A H. Al-shyyab (eds.), Archaeozoology of the Near East V. ARC Publicatioes, Groningen.

414 Bertoni, L., Forresu, D., Coudry, V., F. Audigie, F., Denoix, J-M., 2012. Exostoses on the palmar or plantar aspects of the diaphysis of the third metacarpal or metatarsal bone in horses: 16 cases (2001-2010). Journal of the American Veterinary Medical Association 240:740-747.

Billet, G., C. De Muizon., Mamani Quispe, B., 2008. Late Oligocene mesotheriids (Mammalia, Notoungulata) from Salla and Lacayani (Bolivia): implications for

422 Braun, P.R., Ribeiro, A.M., Ferigolo, J., 2014. Microstructural defects and enamel hypoplasia in teeth of Toxodon Owen 1837 from the Pleistocene of Southern Brazil, Lethaia 47:418-431. 
425 Brown, S.L., Arkins, S., D. J. Shaw., Dixon, P.M., 2008. Occlusal angles of cheek teeth in normal horses with dental disease. The Veterinary Record 162:807-808.

427 Clayton, J.M., 1956. Congenital dental anomalies occurring in 3557 children”, ASDC

428

429

430

431

432

433

434

435

436

437

438

439

440

441

442

443

444

445

446

447

448

449 Journal of Dentristy for Children 23:206-208.

Cowan, I.M., McCrory, W., 1970. Variation in the Mountain Goat, Oreamnos americanus (Blainville). Journal of Mammalogy 51:60-73.

pp.

Croft, D. A., 1999. Placentals: endemic American ungulates; pp. 890-906 in R. Singer (ed), Encyclopedia of Paleontology. Fitzroy Dearborn Publishers. Chicago.

Croft, D. A., 2006. Do marsupials make good predators? Insight from predato-prey diversity ratios. Evolutionary Research 8: 1193-1214.

Croft, D. A., 2016. Horned Armadillos and Rafting Monkeys. The Fascinating Fossil Mammals of South America (Life of The Past). Indiana University Press. 320.

Croft, D. A., Engelman, R.K., Dolgushina, T., Wesney, G., 2018. Diversity and disparity of sparassodonts (Metatheria) reveal non-analogue nature of ancient South American mammalian carnivore guilds. Proceedins B of the Linnean Society. 285:20172012.

Cuesta Ruíz-Colmenares, M.A., Jiménez Fuentes, E., Pérez Pérez, P. J., 2004. Un caso de Hipodoncia en un lofiodóntido (Perissodactyla, Mammalia) del Eoceno Medio de la Cuenca del Duero (Castilla y León, España). Interpretación a luz de la agenesia dentaria humana. Revista Española de Paleontología 19:145-150.

Dacre, K., 2006. Applied Equine Dental Development. American Association of Equine Practitioners, Indianapolis.

Dingwall, J.S., Pass, D.A., Pennock, P.W., Cawley, A.J., 1970. Case report. Multiple cartilaginous exostoses in a dog. The Canadian Veterinary Journal 11:114-119. 
450 Dixon, P.M., Dacre, I., 2005. A review of equine dental disorders. Veterinary Journal

451

452

453

454

455

456

457

458

459

460

461

462

463

464

465

466

467

468

469

470

471

472

473 169:165-187.

Dixon, P.M., Tremaine, W.H., Pickles, K., Kuhns, L., Hawe, C., Maccan, J., McGorum, B.C., Railton, D.R., Brammer, S., 1999. Equine dental disease part 2: a longterm study of 400 cases: disorders of development and eruption and variations in position of the cheek teeth. Equine Veterinary Journal 31:519-528.

Easley, J. 2006. Equine Dental Developmental Abnormalities. American Association of Equine Practitioners. Indianapolis.

Fernández García, M. 2018. Descripción dentaria y osteológica, anatomía funcional, paleoneurología, sistemática y filogenia de la familia Mesotheriidae (Mammalia, Notoungulata). PhD dissertation, Universidad Nacional de Cuyo, Mendoza, Argentina, $385 \mathrm{pp}$.

Fernández-Monescillo, M., Mamani Quispe, B., François, P., Antoine, P-O., 2018. Functional Anatomy of the Forelimb of Plesiotypotherium achirense (Mammalia, Notoungulata, Mesotheriidae) and Evolutionary Insights at the Family level. Journal of Mammalian Evolution. 25: 197-211.

Francis, J. C. 1965. Los géneros de la subfamilia mesotheriinae (Typotheria, Notoungulata) de la República Argentina. Boletín del Laboratorio de Paleontología de Vertebrados 1:7-31.

Garzione, C.N., Hoke, G.D., Libarkin, J.C., Withers, S., Macfadden, B., Eiler, J., Ghosh, J.P, Mulch, A., 2008. Rise of the Andes. Science 320:1304-1307.

Gavanier, M., A. Blum, A., 2017. Imaging of benign complications of exostoses of the shoulder, pelvic girdles and appendicular skeleton. Diagnostic and Interventional Imaging 98:21-28. 
474 Genovart, M., Negre, N., Tavecchia, G., Bistuer, A., Parpal, L., Oro, D. 2010., The

475

476

477

478

479

480

481

482

483

484

485

486

487

488

489

490

491

492

493

494

495

496

497

498 Young, the Weak and the Sick: Evidence of Natural Selection by Predation. PLoS One 5:e9774.

Gillette, D.D., Ray, C.E., 1981. Glyptodonts of North America. Smithsonian Contitributions Paleobiology 255.

Gomes Rodrigues, H., Herrel, A., G. Billet, G., 2017. Ontogenetic and life history trait changes associated with convergent ecological specializations in extinct ungulate mammals. Proceedings of the National Academy of Sciences of the United States of America 114:1069-1074.

Gómez-Olivencia, A., Arcederedillo, D., Rios-Garaizar, J., Garate, D., Iriarte, E., Ziortza San Pedro., 2011. Dental Anomalies in the Mandible of Capra pirenaica: Presence of Two Permanent fourth Premolars in a Pleistocene Wild Goat from Arlanpe Cave (Bizkaia, Northern Spain). International Journal of Osteoarchaeology 23:737-745.

Gradstein, F.M., Ogg, J.G., Schmitz, M.D., Ogg, G.M., 2012. The Geological Time Scale 2012. Volume 2. Amsterdam, Elsevier.

Grahnén, H., 1956. Hypodontia in the permanent dentition. A clinical and genetical investigation. Odontologisk Revy 7:5-100.

Greer, M., Greer,J.K., Gilligham, J., 1977. Osteoarthritis in Selected Wild Mammals. Proceedings of the Oklahoma Academy of Science 57:39-43.

Gregory-Wodzicki, K.M., Mcintosh, W.C., Velasquez, K., 1998. Climatic and tectonic implications of the late Miocene Jakokkota flora, Bolivian Altiplano. Journal of South American Earth Sciences 11:533-560.

Gregory-Wodzicki, K. M., 2002. A late Miocene subtropical-dry flora from the northern Altiplano, Bolivia. Palaeogeography, Palaeoclimatology, Palaeoecology 

$180: 331-348$.

500 Guérin, C., Faure, M., 2013. Un Nouveau Toxodontidae (Mammalia, Notoungulata) du 501 Pléistocène supérieur du Nordeste du Brésil. Geodiversitas 36:155-205.

Hoffstetter, R; C. Martinez; M., and P. Tomasi. 1972. Nouveaux gisement de Mammifères néogènes dans les couches rouges de 1'Altiplano bolivien. Comptes Rendus de l'Académie des Sciences Paris 275:739-742.

Jablonski, N.G., 1992. Dental agenesis as evidence of possible genetic isolation on the colobine monkey, Rhinopithecus roxellana. Primates 33:371-376.

Kapadia, H., Mues, G., D’Souza, R., 2007. Genes affection tooth morphogenesis. Orthodontics and Craniofacial Research 93: 237-244.

509 Khurana, J.S. Bone Pathology. Humana Press. 416 pp.

510 Kraglievich, L., 1934. La antigüedad pliocena de las faunas de Monte Hermoso y Chapadmalalal deducidas de su comparación con las que le precedieron y sucedieron. Imprenta E1 Siglo ilustrado. Montevideo 939:1- 136.

Küchler, E.C., A. Lips, A., Tannure, P.N., Ho, B.; Costa, M.C., Granjeiro, J.M., Vieira, A.R. Tooth agenesis association with self-reported family history of cancer. Journal of Dental Research 92: 149-155.

Lamb, S. 2016., Cenozoic uplift of the Central Andes in northern Chile and Boliviareconciling paleoaltimetry with the geological evolution. Canadian Journal of Earth Sciences 53:1227-1245.

Lavelle, C.L., Moore, W.J., 1973. The Incidence of Agenesis and Polygenesis in the Primate Dentition. American Journal of Physical Anthropology 38:671-679. Journal of Osteoarchaeology 20:396-404. 
524 Lynch M., McCraken, H., Scolocombe, R., 2002. Hyperostotic bone disease in red

525

526

527

528

529

530

531

532

533

534

535

536

537

538

539

540

541

542

543

544

545

546

547

548 pandas (Ailurus fulgens). Journal of Zoo and Wildlife Medicine 33:263-271.

Marshall, L. G., Hoffstetter, R., Pascual, R., 1983. Mammals and Stratigraphy: Geochronology of the Continental Mammal-Bearing Tertiary of South America. Palaeovertebrata 1-93.

McDonald, H. G. 1989., Not all ground sloth bones are pathological: but some are. Journal of Vertebrate Paleontology 9:32A.

McKenna, M., Bell, S.K., 1997. Classification of Mammals: Above the Species Level. Columbia University Press, New York, 640 pp.

Mead, A.J., 1999. Enamel hypoplasia in Miocene rhinoceroses (Teleoceras) from Nebraska: evidence of severe physiological stress. Journal of Vertebrate Paleontology 19:391-397.

Mestrinho, L.A., Louro, J.M., Gordo, I.S., Niza, M.M.R.E., Requicha, J. F., Force, J.G., Gawor, P., 2018. Oral and dental anomalies in purebred, brachycephalic Persian and Exotic cats. Journal of the American Veterinary Medical Association 253:66-72.

Mostowska, A., Briedzia, B., Jagodziniski, P.P., 2006. Axis inhibition protein (AXIN2) polymorphisms may be a risk factor for selective tooth agenesis. Journal of Human Genetic 51:262-266.

Natsume, A., Koyasu, K., Hanamura, H., Nakagaski, H., Oda, S., 2005. Variation in the number of teeth in wild Japanese serow (Naemorhedus crispus). Archives of Oral Biology 50:849-860.

Pavlica, Z., Erjavec, V., Petelin, M., 2001. Teeth abnormalities in the dog. Acta Veterinaria Brno 70:65-72.

Paz, R., Kramarz, A., Bond, M., 2011. Mesotheriid (Mammalia, Notoungulata) remains 

from the Colhuehuapian Beds (Early Miocene) of Chichinales Formation, Río Negro Province, Argentina. Ameghiniana 48:264-269.

Pemberton, T.J., Das, P., Patel, P.I., 2005. Hypodontia: genetics and future perspectives. Brazilian Journal of Oral Sciences 4:695-706.

Peres, R.C.R., Scarel-Caminaga, R.M., Santo, A.R.R., Line S.R.P., 2005. Association between PAX-9 promoter polymorphisms and hypodontia in humans. Archives of Oral Biology 50:861-871.

Polder M.A., Van’t Hof, M.A., Van Der Linden, F.P., Kuijpers-Jagtman, A.M., 2004. A meta-analysis of the prevalence of dental agenesis of permanent teeth. Community Dentistry and Oral Epidemiology 32:217-226.

Pool, R.R., Carrig, C.B., 1972. Multiple Cartilaginous Exostoses in a Cat. Vertebrate Pathology 9:350-359.

Prevosti, F.J., Forasiepi, A.M., 2018. Evolution of South American Mammalian Predators During the Cenozoic: Paleobiogeographic and Paleoenvironmental Contingencies. Springer Geology. 196 pp.

Prummel, W., 1987. The faunal remains from the Neolithic site of Hekelingen III. Helinium 27:190-258.

Pujos, F., De Iuliis, G., Mamani Quispe, B., Adnet, S., Andrade Flores, R., Billet, G., Fernández-Monescillo, M., Marivaux, L., Münch, P., Prámparo, M.B., and Antoine, P-O., 2016. A new nothrotheriid xenarthran from the early Pliocene of Pomata-Ayte (Bolivia): new insights into the caniniform-molariform transition in sloths. Zoologial Journal of the Linnean Society 178:679-712.

Ramzan, P.H., Dixont, P. M., Kempson, S.A., Rossdale, P.D., 2001. Dental dysplasia and oligodontia in a throughbred colt. Equine Veterinary Journal 33:99-104. 
Barranca, Chubut Province, Argentina: phylogeny and systematics; pp. 148-165 in Madden, R. H. Carlini, H. H., Vucetich, M. G, and Kay, R. F (eds). The Paleontology of Gran Barranca: Evolution and Environmental Change through the Middle Cenozoic of Patagonia. Cambridge University Press, Cambridge.

Roth, S., 1903. Los ungulados sudamericanos. Anales del Museo de La Plata. Sección Paleontologia, 5:1-36.

Salesa M.J., Anton, M., Siliceo, G., Pesquero, M.D., Alcala, L., 2014. First evidence of pathology in the forelimb of the late Miocene saber-toothed felid Promegantereon ogygia (Machairodontinae, Smilodontini). Anatomical Record 297:1090-1095.

Silver, G.M., Bargley, R.S., Gavin, P.R., Kippenes, H., 2001. Radiographic diagnosis: cartilaginous exostoses in a dog. Veterinary Radiology and Ultrasound 42:231234.

Silverman N.E., Ackerman, J.L., 1979. Oligodontia: a study of its prevalence and variation in 4032 children. Journal of Dentistry for Children 46:470-477.

Simpson G.G., 1948. The beginning of the age of mammals in South America Part 1. Systematics: Marsupialia, Edentata, Condylarthra, Litopterna and Notioprogonia, Bulletin American Museum of Natural History 91:1-232.

Stilton K.T., Hopkins, S.S.B., Davis, E.B., 2016. Osteopathology in Rhinocerotidae from 50 Million Years to the Present. PLoS One 11:e0146221.

Temple S.A., 1987. Do Predators Always Capture Substandard Individuals Disproportionately From Prey Populations?. Ecology 68:669-674.

Thenius, E., 1989. Mammalia: Zähne ung Gebiss der Säugetiere in J. Niethammer, H. Schliemann, and D. Starck (eds.) Handbuch der Zooologie, Volume 8. Verlag Walter de Gruyter and Co. Berlin. 513 pp. [German 1-164]. 
599 Torres, T de., Ortiz, J.E., Cobo, R, Julià, R., Camacho, A., Puch, C., Llamas, J.F., 2005.

600 Presence of two cave bear species in La Lucia cave (Lamasón, Cantabria, N

601 Spain): Ursus deningeri von Reichenau and Ursus spelaeus Rosenmüller-

602 Heinroth. MUNIBE Antropologia-Arkeologia 57;103-122.

603 Vigal, C. R., Machordom, A., 1985. Tooth Eruption and Replacement in the Spanish

$604 \quad$ Wild Goat. Acta Theriologica 30:305-320.

605 Villarroel, C., 1974. Les mésothérinés (Notoungulata, Mammalia) du Pliocène de

606 Bolivie et leurs rapport avec ceux d'Argentine. Annales de Paléontologie

$607 \quad 60: 245-281 .[$ [French 245-281]

608 Villarroel, C., Marshall, L. G., 1983. Two New Late tertiary Marsupials

609 (Hathlyacyninae and Sparassocyninae) from the Bolivian Atiplano. Journal of

$610 \quad$ Paleontology 57:1061-1066.

611 Waibl, H., Gasse,H., Hashimoto, Y., 2005. Nomina Anatomica Veterinaria. Hannover:

612 International Committee on Veterinary Gross Anatomical Nomenclature, World

613 Association of Veterinary Anatomis, Hannover.

614 Wisth, P.J., Thunold, K., Böe, O.E., 1974. Frequency of hypodontia in relation to tooth 615 size and dental arch width. Acta Odontologica Scandinavica 32: 201-206.

616 Zittel, K.A., 1893. Handbuch der Palaeontologie, Volume IV. Vertebrata (Mammalia).

617 Druck und Verlag von R. Oldenbourg, Munchen und Leipzig, 590 pp.

618

619 
620

621

622

623

624

625

626

627

628

629

630

631

632

633

634

635

636

637

638

639

640

641

642

643

644

\section{Figure Captions}

Figure 1. Location map of Achiri, Pacajes Province, La Paz Department, Bolivia.

General map of Bolivia (a), detailed map showing the location of the Mauri and Ulloma formations, and hills ('cerros') surrounding the Achiri Village (b). [prepared for page width]

Figure 2. Skulls of Plesiotypotherium achirense with digital reconstruction of the teeth. Pathological skull (MNHN-Bol-V12617) (a-d), non-pathological skull (MNHN-Bol-V 8507) in mirror view (e-h). Lateral right views (a-b, e-f); ventral views (c-d, g-h). In pink color and "o" the upper premolars (P3-P4), in red the upper molars (M1-M2), and “*” appear the deformed overgrown M1-M2. In grey appears the usual aspect of upper teeth of Plesiotypotherium achirense. Scale bar represents $5 \mathrm{~cm}$. [prepared for page width]

Figure 3. Mandible of Plesiotypotherium achirense with digital reconstruction of the teeth. Pathological mandible (MNHN -Bol-V 12617) (a-d); mandible of Plesiotypotherium achirense (MNHN-Bol-V 12669) (e-f). Right lateral views (a-b, e-f); occlusal views (c-d, g-h). In red color and “*” are figured the pathological p4. In grey appears the usual aspects of lower teeth. Scale bar represents $5 \mathrm{~cm}$. [prepared for full page width]

Figure 4. Skeletal reconstruction of the pathological individual of Plesiotypotherium achirense from Achiri, with distinct osteological pathologies of postcranial elements (MNHN-Bol-V 12617); blue denotes osteological remains that were unearthed. Lateral view of the right scapula showing the osteological callus in the hamatus process 
645 (acromion) (a); Head of the radius in cranial and proximal views respectively (b-c);

646 Proximal epiphysis of the ulna in medial view (d); Mt III in proximal view (e); Second

647 phalanx of the pes in dorsal view (f). Exostosis as visible in the articular edges (b-d); in

648 addition, show a weak cortical bone structure in their broken areas (c-d). Reconstruction

649 of Plesiotypotherium achirense made by Juan Esteban Rodriguez

650 (http://juanestebanartwork.com/). [prepared for page width]

651

652 Figure 5. Pathological occlusal sequence reconstruction (upper left molar premolar

653 series and lower left molar-premolar series) during the life time of Plesiotypotherium

654 achirense (MNHN-Bol-V 12617). Early stages of occlusion (typical stage) (a);

655 hypodontia of $\mathrm{m} 1$ and overgrowth of the crista 2-crochet and metaloph of the M1 (b);

656 hypodontia of $\mathrm{m} 2$ and overgrowth of the mesial part (protoloph and parastyle) area of

657 the M2 (c). Black dotted lines and "*” show the M1-M2 overgrown. [prepared for

658 column width]

659

660

661 

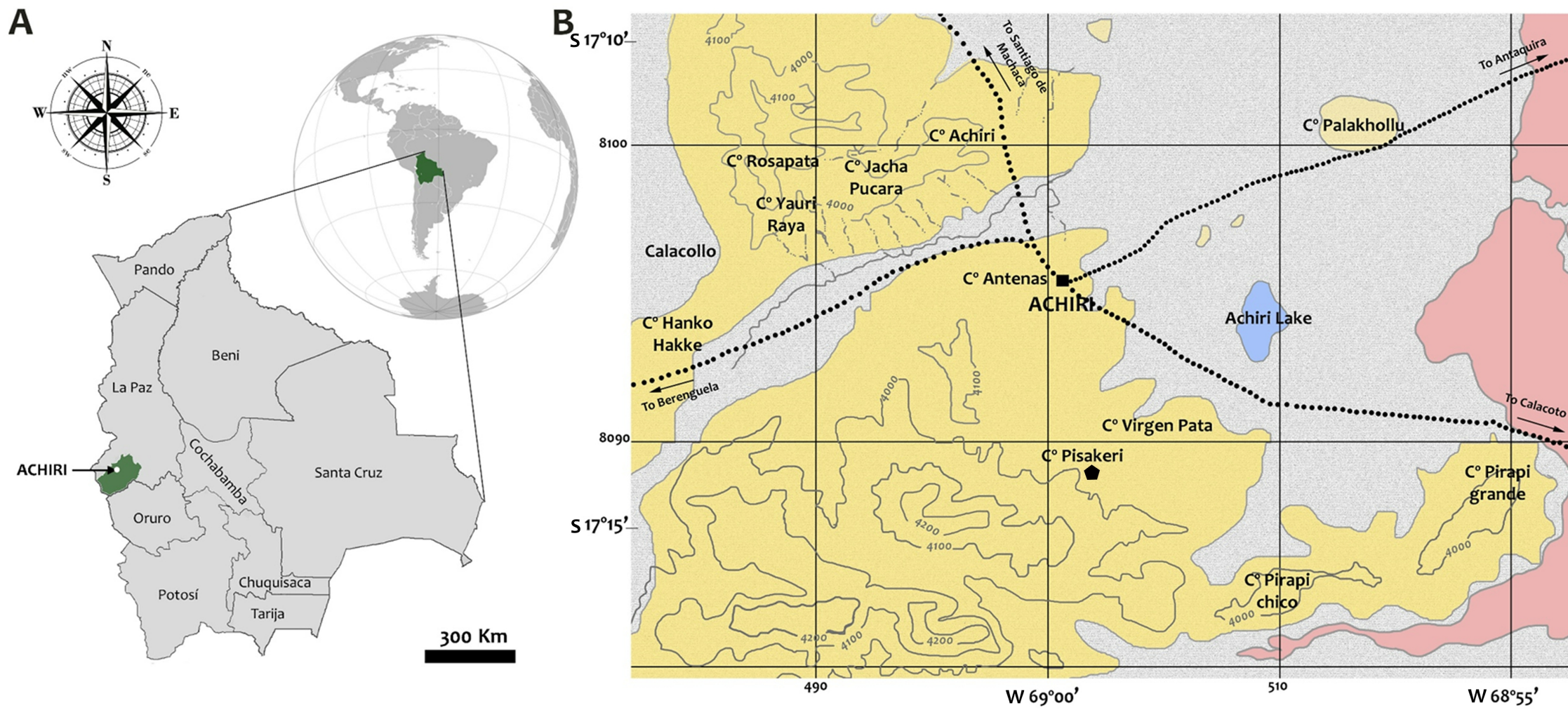

Legend

Fm Mauri

Fm Ulloma

Lake

_ Contour lines

..... Roads

achiri

- CoPisakeri

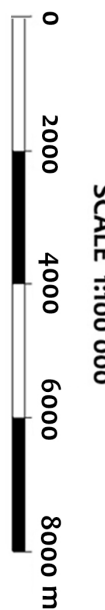



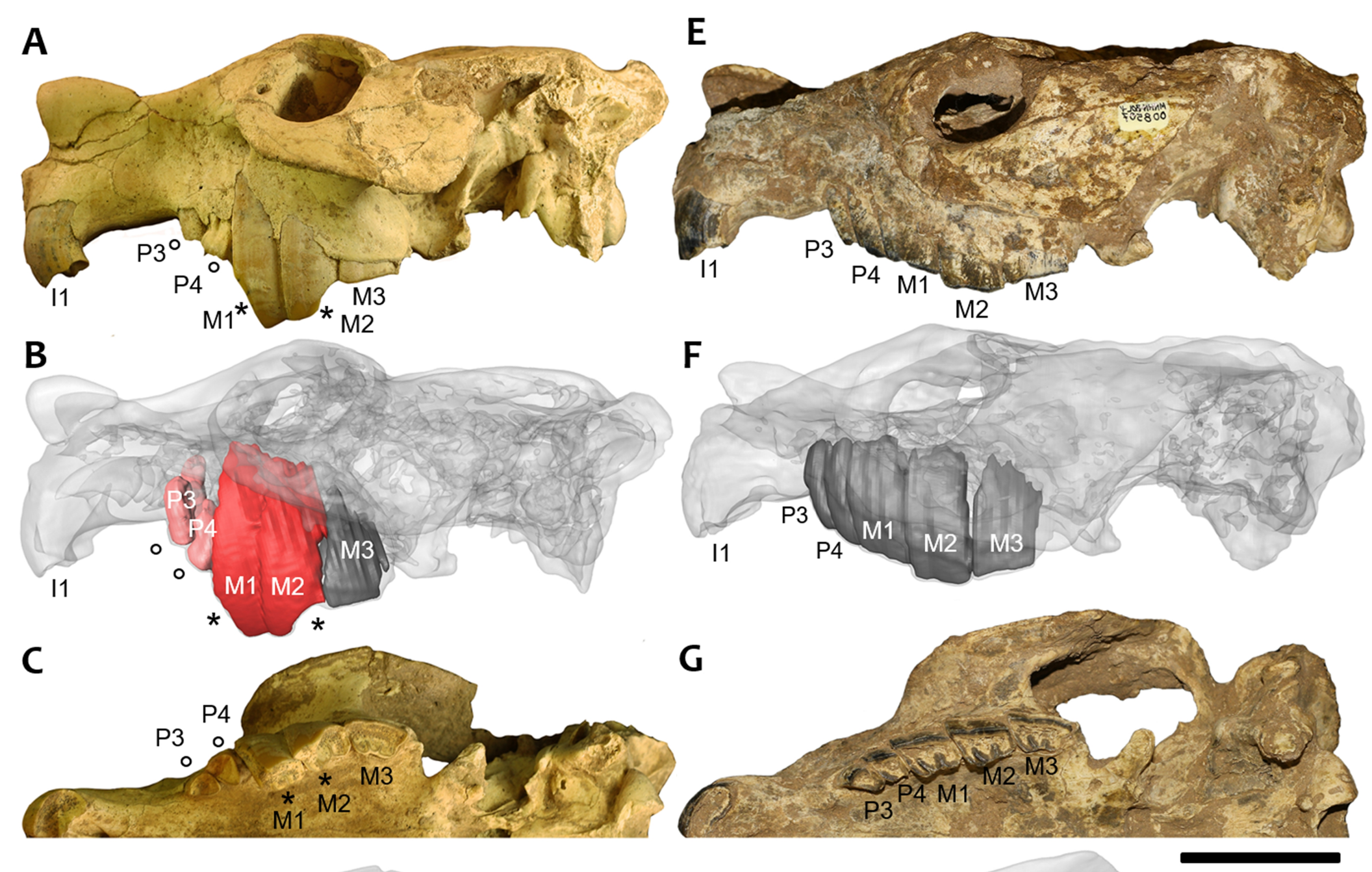

D

$$
\text { P3० }{ }^{\mathrm{P}} \mathrm{N}^{\mathrm{M}} \mathrm{M} 2 \mathrm{M3}
$$

H P3 $44 \sqrt{M 1} \sqrt{M 3}$ 


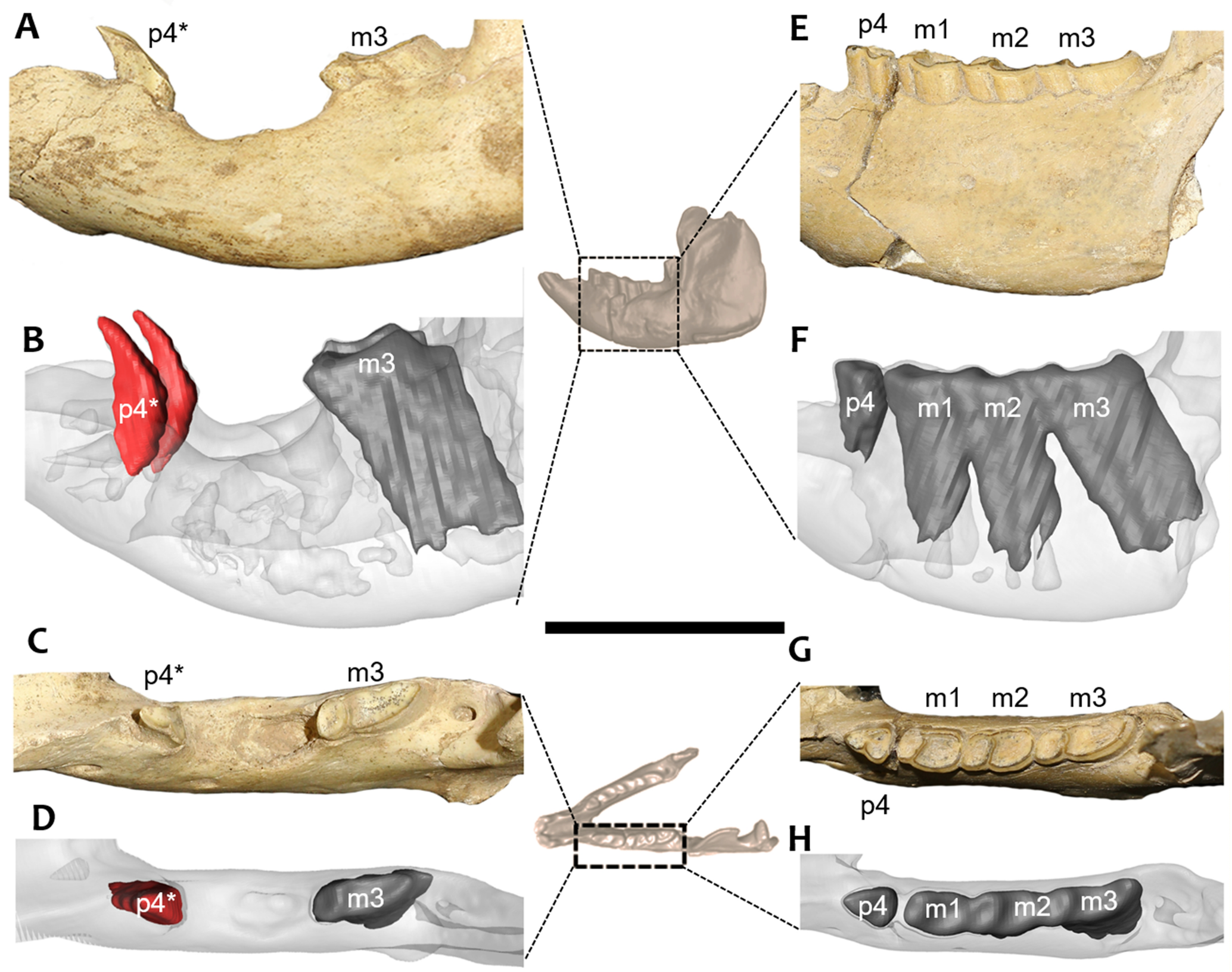




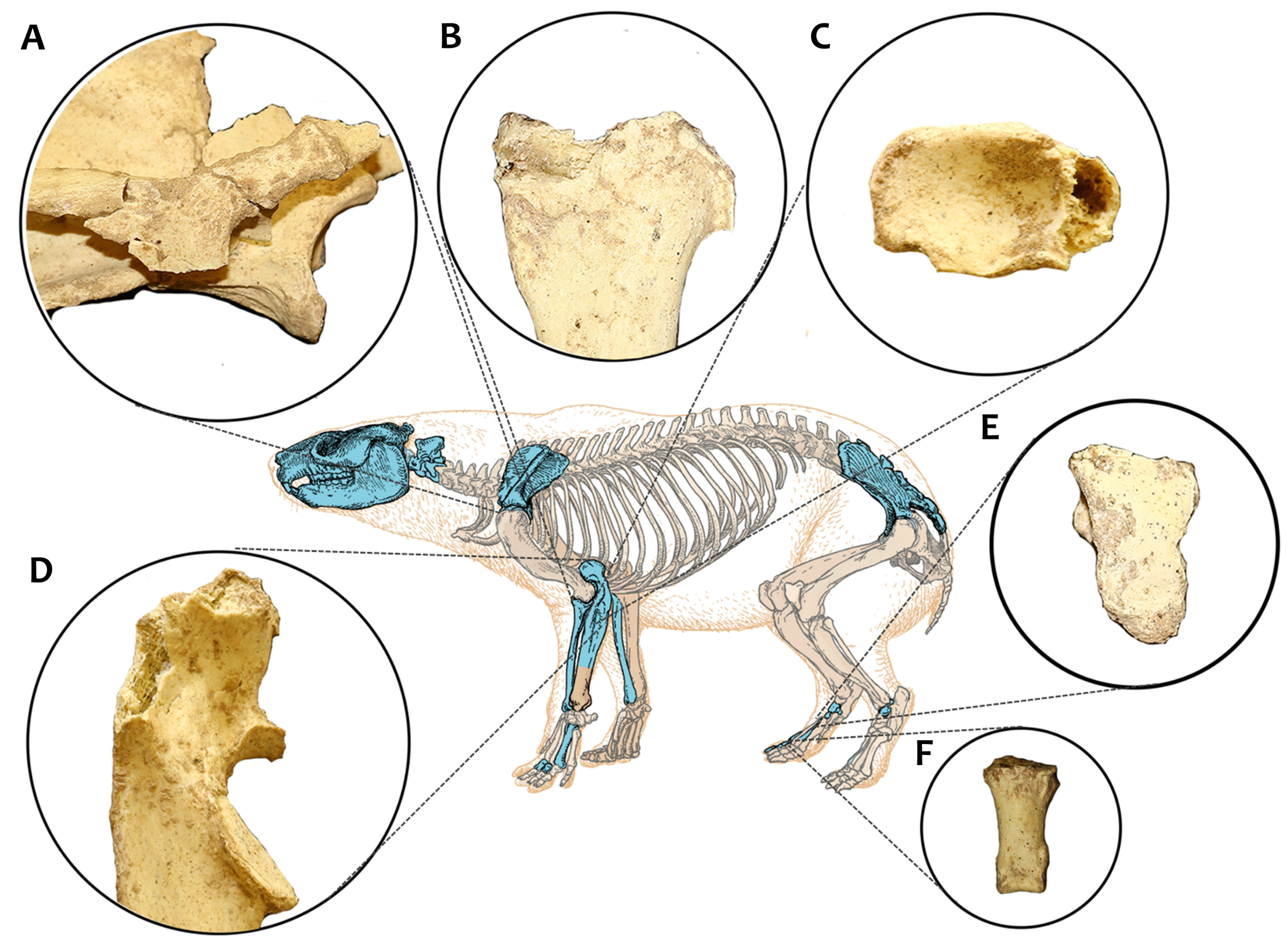


A

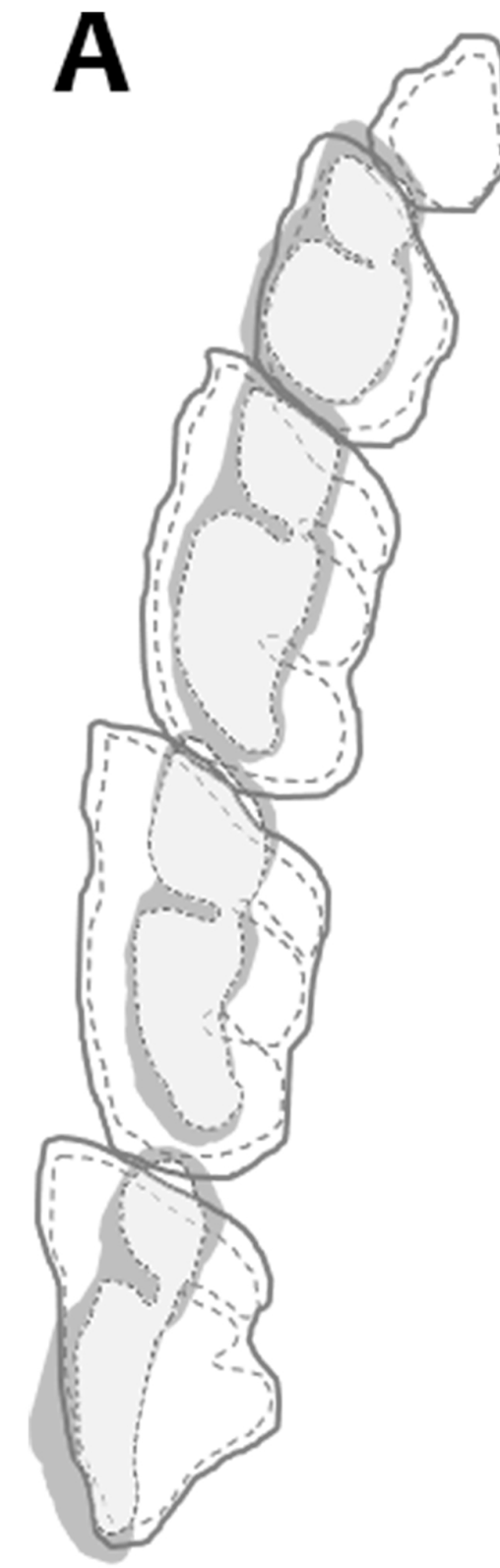

B

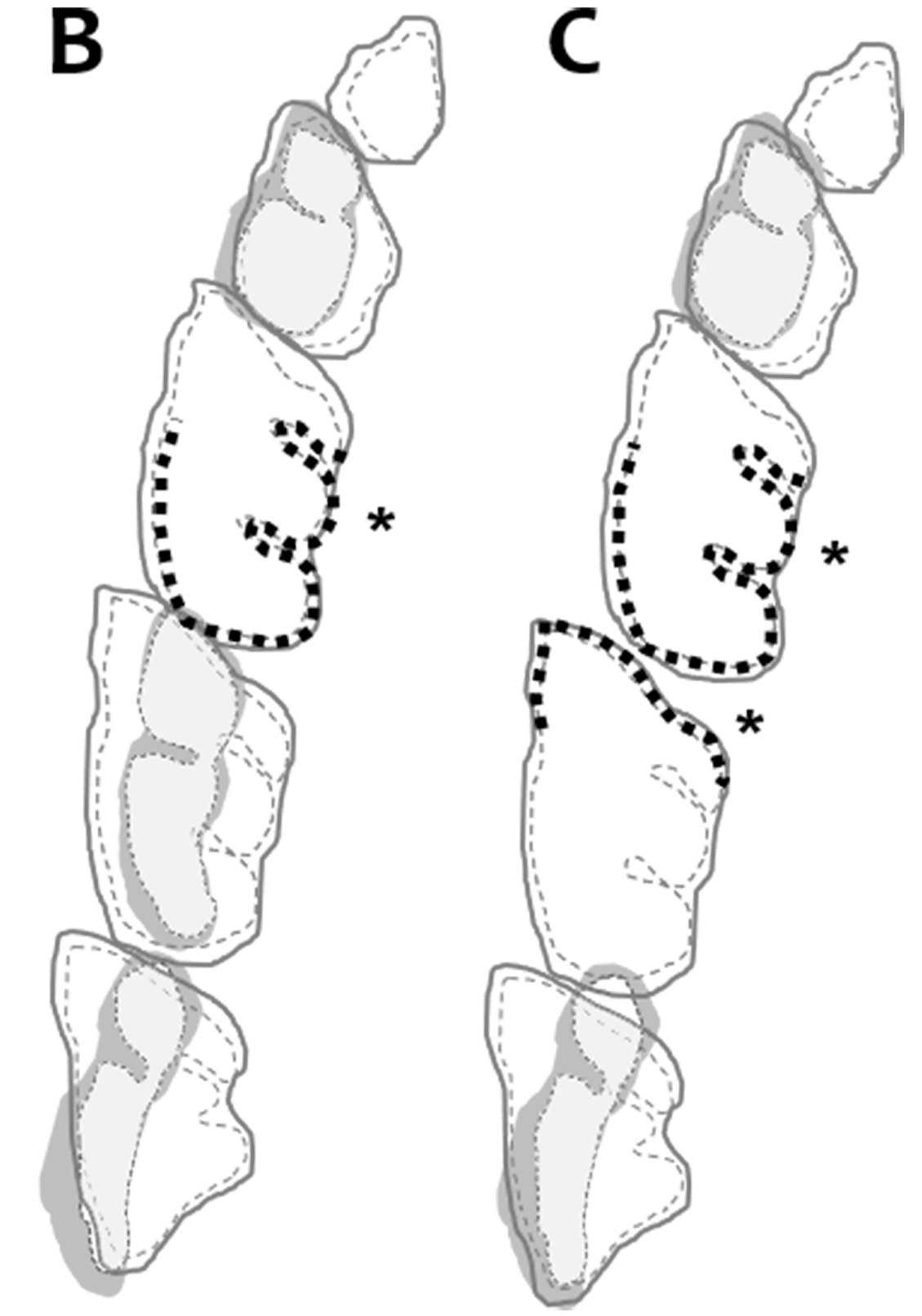




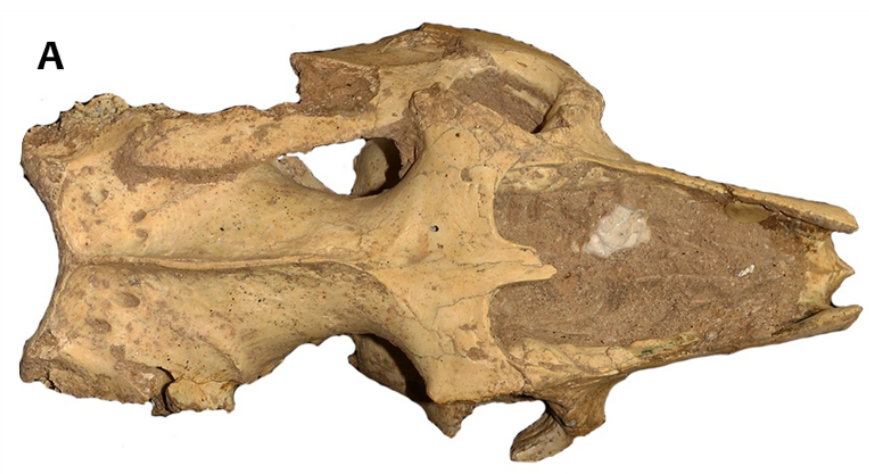

B

C

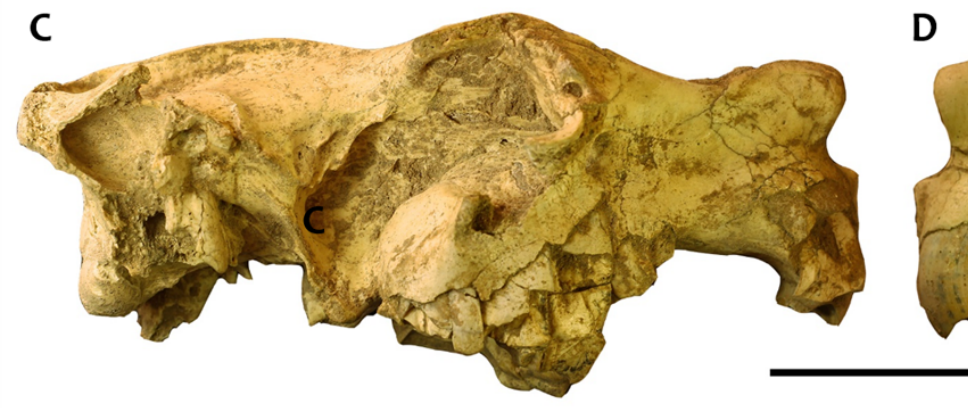

D
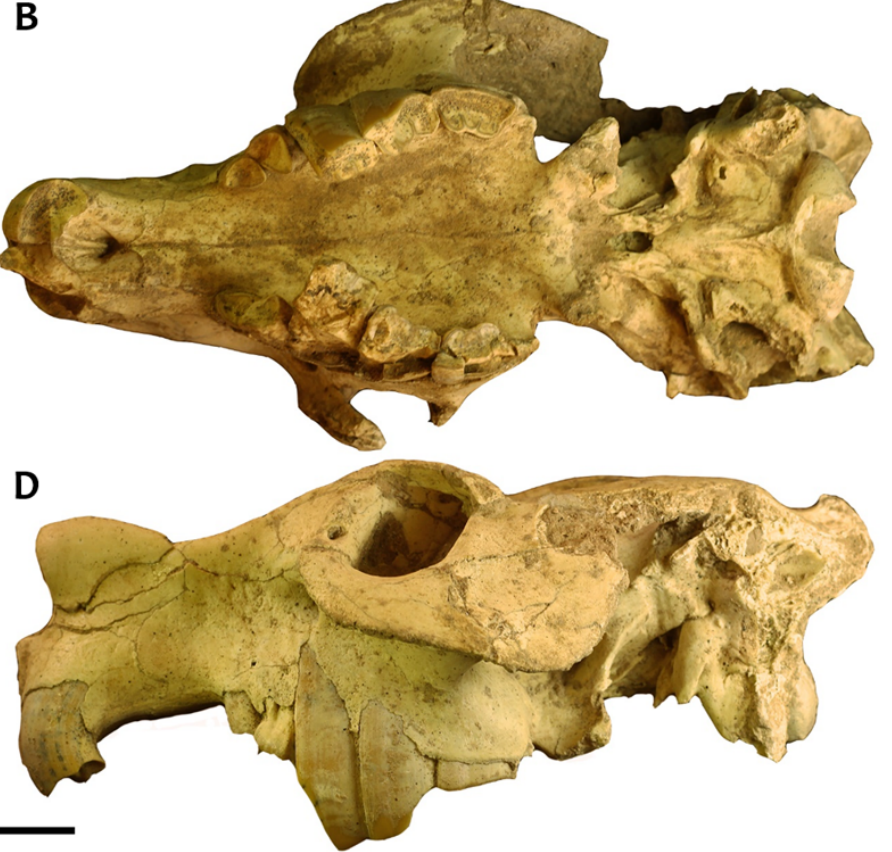

Figure 1 Supplementary material 1. Pathological skull of the mesotheriid notoungulate Plesiotypotherium achirense (MNHN-Bol-V 12617), from the late Miocene of Achiri, Bolivia. Dorsal (a); ventral (b); lateral right (c); lateral left (d) views. Scale bar represents $5 \mathrm{~cm}$. 


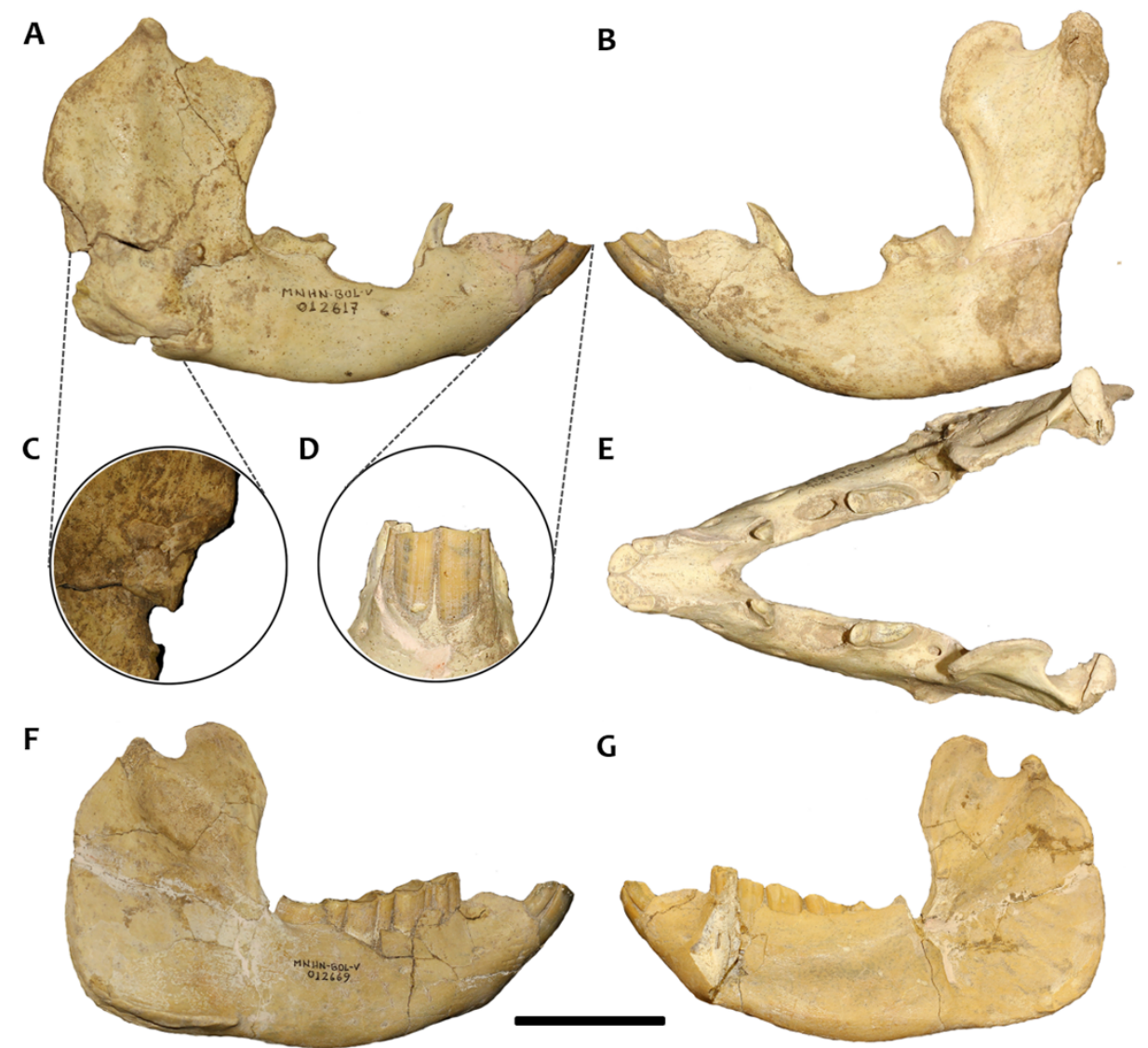

Figure 2 Supplementary material 1. Mandibles of Plesiotypotherium achirense. Pathological mandible (MNHN-Bol-V12617) (a-e) in lateral right (a); lateral left (b); detail of caudomedial border of the mandibular ramus (c); ventrorostral border (d); dorsal view (e). Non-pathological mandible (MNHN-Bol-V 12669) (f-g) in lateral right (f), medial views $(\mathrm{g})$. Scale bar represents $5 \mathrm{~cm}(\mathrm{C}$ and $\mathrm{D}$ are not to scale). 


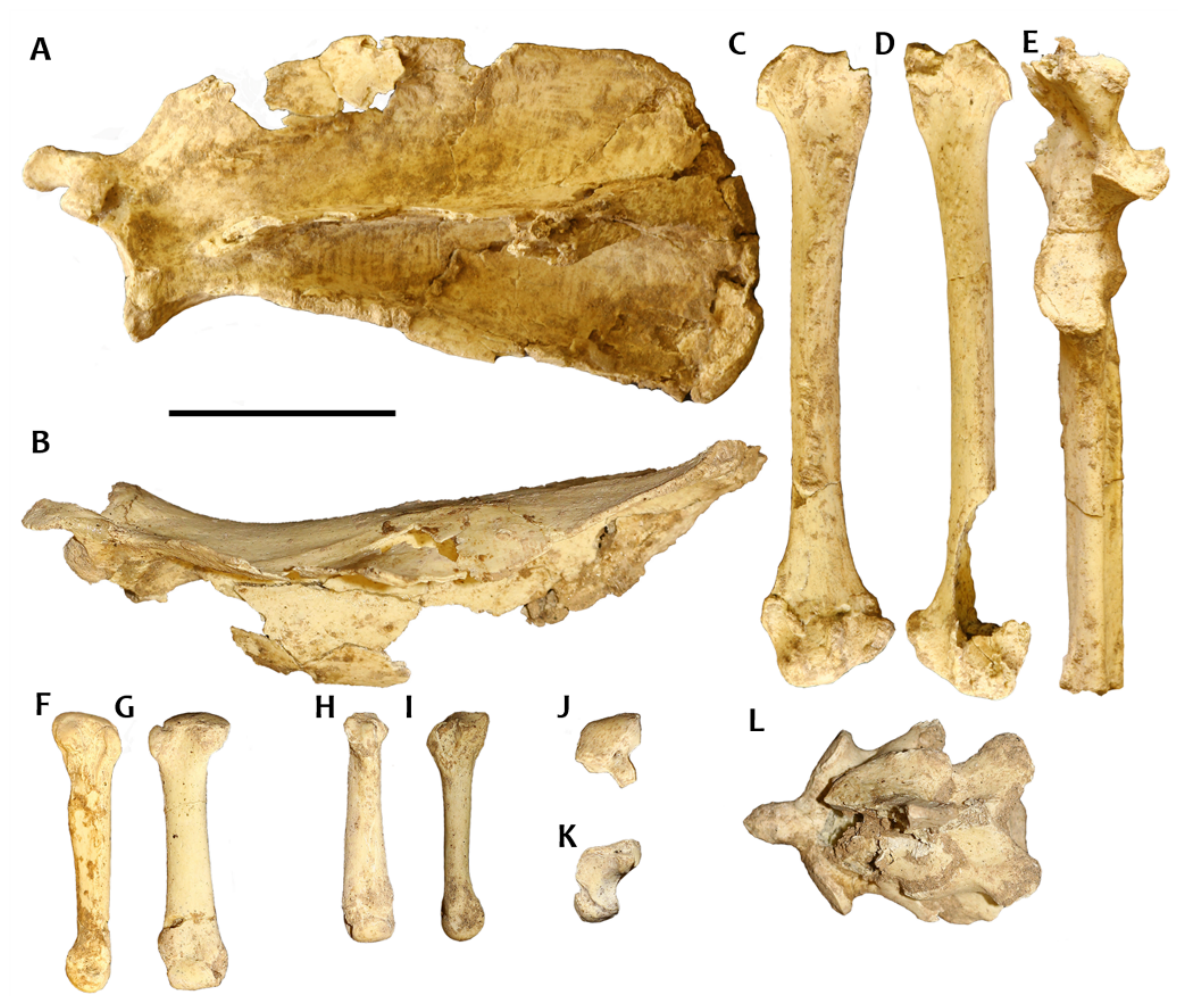

Figure 3 Supplementary material 1. Scapula, forelimb elements, axis and third cervical vertebra (C3) of Plesiotypotherium achirense (MNHN-Bol-V 12617). Left scapula in lateral and cranial views respectively $(a, b)$; right radius in cranial view (c); left radius in cranial view (d); proximal epiphysis of left ulna (e); left Mc IV in medial and dorsal views respectively (f-g); right Mc V in dorsal and medial views respectively (h-i); left scaphoid in dorsal and distal views respectively (j-k); axis and third cervical vertebra (C3) in dorsal view (1). Scale bar represents $5 \mathrm{~cm}$. 


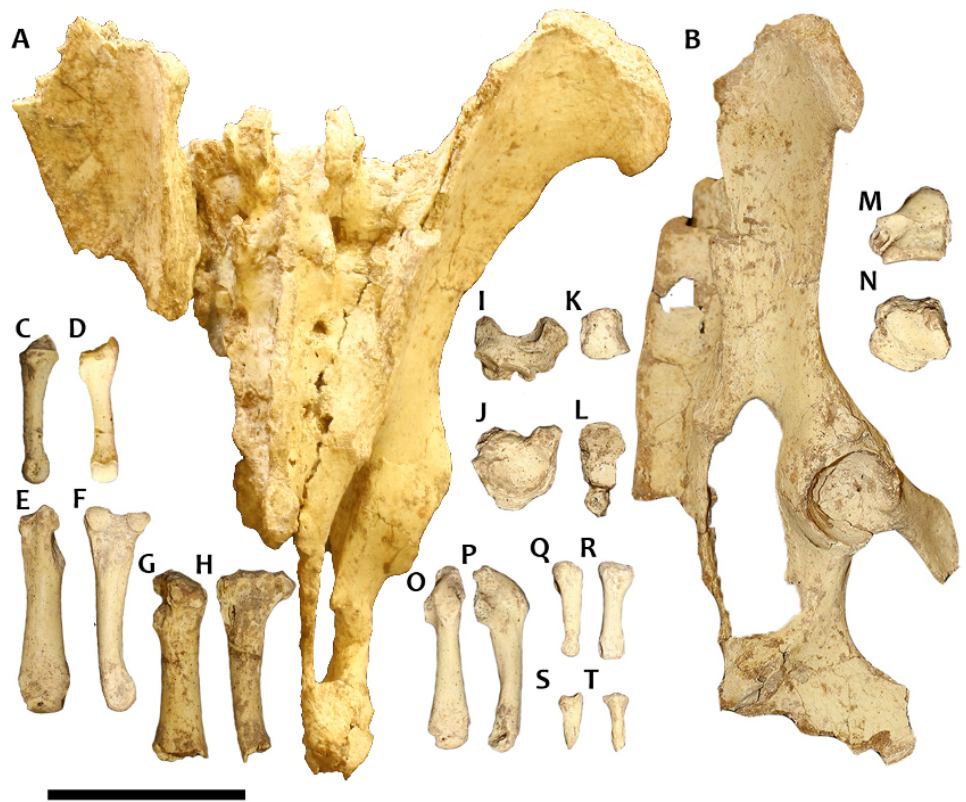

Figure 4 Supplementary material 1. Pelvis, sacrum, and hind limb of Plesiotypotherium achirense (MNHN-Bol-V 12617). Fused pelvis and sacrum in cranial and right lateral views respectively (a-b); left Mt I in medial and plantar views respectively (c-d); right Mt II in dorsal and medial views respectively (e-f); left Mt III in dorsal and medial views respectively(g-h); left navicular in dorsal and proximal views respectively (i-j); left ectocuneiform in dorsal and distal views respectively (k-1); left cuboid in dorsal and proximal views respectively (m-n); right Mt V in dorsal and lateral views respectively (o-p); second right phalanx of the digit $\mathrm{V}$ in lateral and dorsal views respectively (q-r); third right phalanx of the digit $\mathrm{V}$ in lateral and dorsal views respectively $(\mathrm{s}-\mathrm{t})$. Scale bar represents $5 \mathrm{~cm}$. [prepared for page width] 

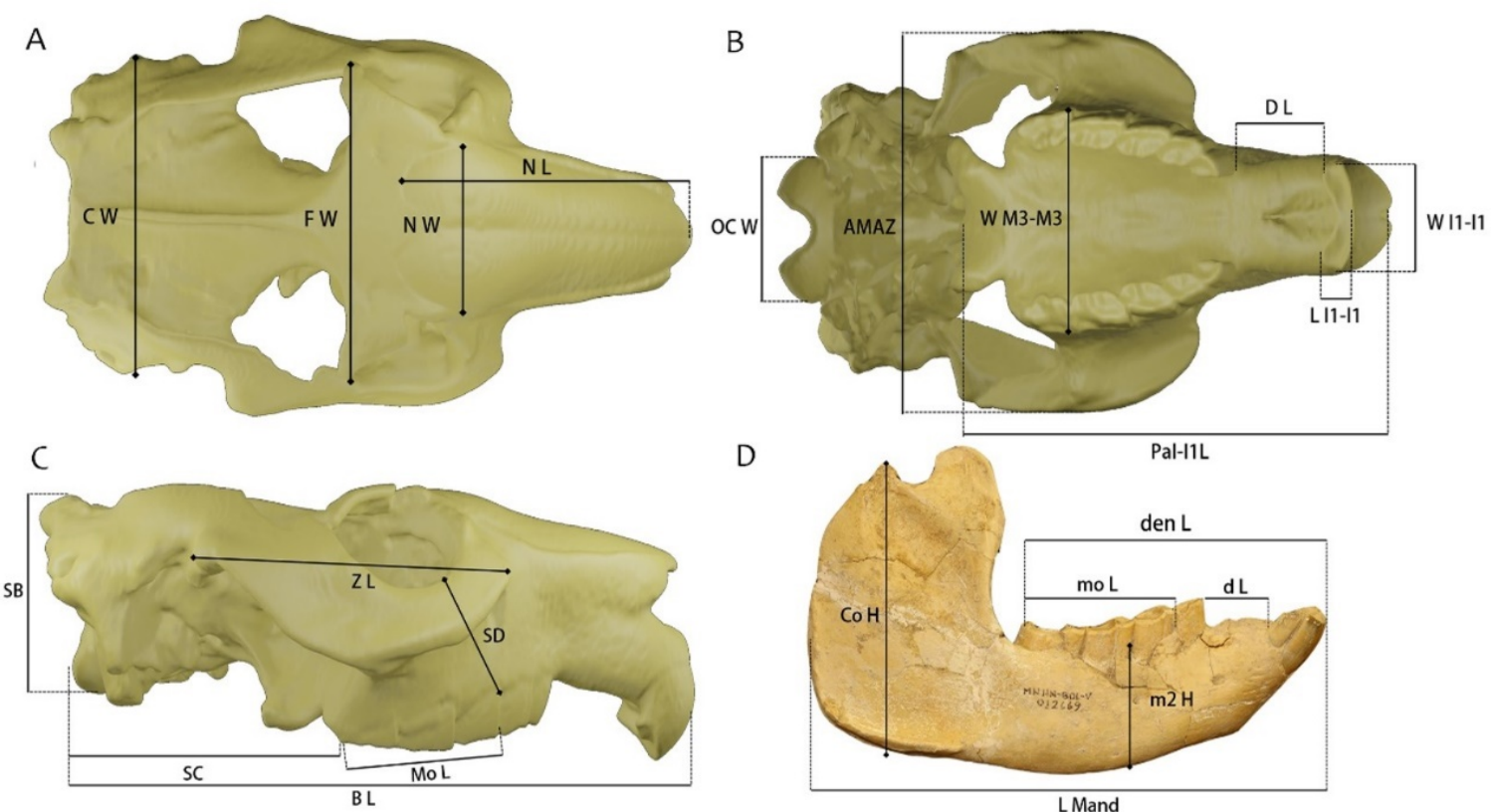

$E$

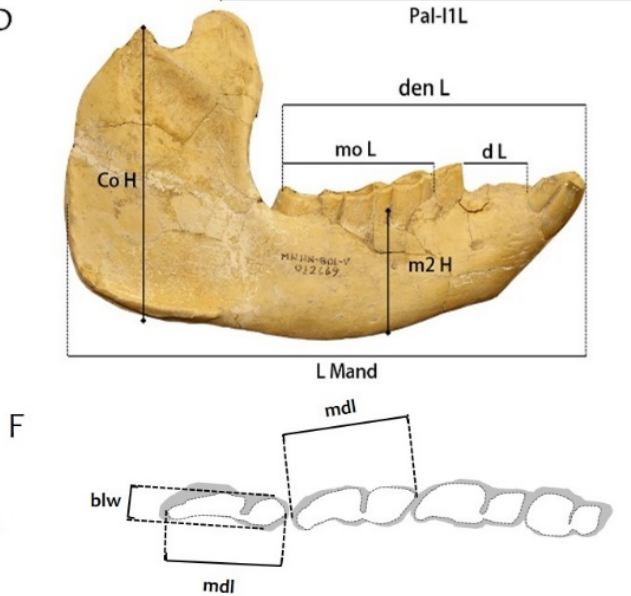

Figure 5 Supplementary material 1. Measurements for the cranial, mandibular and dental elements of Plesiotypotherium achirense. Skull in dorsal, ventral and lateral views, respectively (c-d); Mandible in lateral view (d); upper teeth in occlusal view (e); lower teeth in occlusal view (f). 


\begin{tabular}{ll} 
Abbreviation & Description \\
\hline N L & Nasal length \\
N W & Nasal width \\
F W & Maximal frontal width \\
C W & Maximal skull caudal width \\
BL & Basal skull length \\
Mo L & Upper molar series length \\
SC & Length of the posterior portion of the skull, measured from the occipital condyle to the distal m3 border \\
SB & Occipital height, measured from the base of the foramen magnum to the top of the occipital region \\
SD & Depth of the face under the orbit measured from the limit between molar and premolar tooth sequence \\
Z L & to the nearest point of the orbit. \\
L I1-I1 & Maximal length of the zygomatic arch \\
W I1-I1 & I1-I1 incisor length, measured from the rostral contact of both I1 to the caudal border between both I1 \\
D L & I1-I1 incisor width \\
W M3-M3 & Upper diastema length \\
AMAZ & Width between the both M3 parastyles \\
OC W & Maximal width of the zygomatic arch \\
Pal-I1 L & Occipital condyle width \\
d L & Maximal length of the palate to the labial border of the I1. \\
mo L & Lower diastema length \\
den L & Lower molar sequence length \\
m2 H & Lower dental length \\
Co H & Mandibular body height at m2 level \\
Mand L & Height of the mandibular condyle to the base of the mandibular ramus \\
\hline
\end{tabular}


Table 1 Supplementary material 1. Description and summary of cranial and mandibular measurements (in mm) of Plesiotypotherium achirense.

\begin{tabular}{|c|c|c|c|c|c|c|c|c|c|c|c|c|c|c|c|c|}
\hline Inventory number / Measurements & B L & $\mathbf{Z} \mathbf{L}$ & D L & SC & Mo L & SB & AMAZ & $\mathbf{N} \mathbf{L}$ & $\mathbf{N} \mathbf{W}$ & F W & D L & $\begin{array}{l}\text { W I1- } \\
\text { I1 }\end{array}$ & L I1-I1 & $\begin{array}{l}\text { W M3- } \\
\text { M3 }\end{array}$ & AMAZ & $\begin{array}{l}\text { OC } \\
\text { W }\end{array}$ \\
\hline MNHN-Bol-V 12617 & & 76.17 & & & 52.6 & 56 & 128.82 & 98.52 & 50 & 99.4 & 32.13 & 29 & 18 & 62.78 & 128.82 & 39.1 \\
\hline MNHN.F.ACH 26 (Holotype) & 192 & 94.58 & 34 & 88 & 53.2 & 61 & 120.09 & 95.07 & 53 & 99.4 & 29.25 & 30 & 17 & 70.07 & 120.09 & 44.2 \\
\hline MNHN-Bol-V 8507 & 189 & 94.34 & 35 & 83 & 51.2 & 52 & 128.75 & 96.71 & 57 & 92.32 & 31.04 & 30 & 15 & 68.73 & 128.75 & 45.4 \\
\hline MNHN.F.ACH 23 & & 90.88 & 38 & & 53.1 & & 125.5 & 98.18 & 50 & 92.46 & 25.69 & 32 & 17 & 74.48 & 125.5 & \\
\hline MNHN.F.ACH 63 & & 85.26 & & & & & 121.66 & 85.76 & 47 & & & 26 & & 73.97 & 121.66 & \\
\hline MNHN-Bol-V 12665 & & 88.7 & 27 & 94 & 46.7 & 63 & & 106.3 & 56 & 92.25 & 28.4 & 23 & 13 & & & \\
\hline MNHN-Bol-V 12664 & & 80.16 & 31 & 76 & 39.3 & & 106.36 & 76.54 & 47 & 79.85 & 25.96 & & 11 & 56.64 & 106.36 & \\
\hline
\end{tabular}

Table 2 Supplementary material 1. Skull measurements (in $\mathrm{mm}$ ) of Plesiotypotheirum achirense. For abbreviations see Figure 5 Supplementary material 1 . 


\begin{tabular}{|c|c|c|c|c|c|c|c|c|c|c|c|c|c|c|c|}
\hline Number & $\begin{array}{c}\text { I1 } \\
\text { MLD }\end{array}$ & $\begin{array}{c}\text { I1BL } \\
\text { W }\end{array}$ & $\begin{array}{c}\text { P3 } \\
\text { MDL }\end{array}$ & $\begin{array}{c}\text { P3 } \\
\text { BLW }\end{array}$ & $\begin{array}{c}\text { P4 } \\
\text { MDL }\end{array}$ & $\begin{array}{c}\text { P4 } \\
\text { BLW }\end{array}$ & $\begin{array}{c}\text { M1 } \\
\text { MDL }\end{array}$ & $\begin{array}{c}\text { M1BL } \\
\text { W }\end{array}$ & $\begin{array}{c}\text { M2 } \\
\text { MDL }\end{array}$ & $\begin{array}{c}\text { M2 } \\
\text { BLW }\end{array}$ & $\begin{array}{c}\text { M3 } \\
\text { MDL }\end{array}$ & $\begin{array}{c}\text { M3 } \\
\text { BLW }\end{array}$ & $\mathbf{A}$ & B & $\mathbf{A} / \mathbf{B}$ \\
\hline MNHN-Bol-V 12617 & 11.21 & 10.36 & 10.35 & 8.35 & 10.64 & 8.59 & 15.70 & 11.37 & 18.57 & 11.70 & 19.70 & 10.58 & & & \\
\hline $\begin{array}{l}\text { MNHN.F.ACH } 26 \\
\text { (Holotype) }\end{array}$ & & & 10.04 & 8.53 & 11.51 & 10.35 & 16.08 & 11.55 & 18.16 & 11.62 & 19.67 & 10.91 & 11.9 & 9.66 & 1.23 \\
\hline & & 10.25 & & & & & & & & & & & 12.5 & & \\
\hline MINHIN-BOI- & 18.08 & 5 & 10.3 & 6.87 & 8.01 & 10.23 & 15.88 & 11.43 & 17.02 & 11.28 & 18.81 & 10.08 & 5 & & \\
\hline MNHN.F.ACH 33 & & & & & & & 14.88 & 12.08 & 16.63 & 11.8 & 19.55 & 11.14 & $\begin{array}{c}11.6 \\
4\end{array}$ & & \\
\hline MNHN.F.ACH 28 & 18.845 & 10.17 & 9.15 & 8.47 & 10.18 & 10.34 & 17.52 & 10.15 & 18.89 & 11.29 & 20.21 & 10.79 & $\begin{array}{c}12.4 \\
9\end{array}$ & 9.65 & 1.29 \\
\hline MNHN.F.ACH 19 & 19.63 & 10.81 & 10.52 & 8.47 & 10.69 & 11.16 & 17.02 & 12.25 & 19.84 & 12.96 & 20.74 & 11.52 & $\begin{array}{c}13.9 \\
4\end{array}$ & 9.85 & 1.42 \\
\hline MNHN.F.ACH 39 & & & 10.52 & 8.37 & 10.35 & 11.97 & 17.95 & 11.325 & 17.685 & 11.145 & 19.365 & 10.445 & $\begin{array}{c}11.1 \\
5\end{array}$ & 9.41 & 1.18 \\
\hline MNHN.F.ACH 20 & 15.97 & 8.68 & 8.52 & 6.61 & 11.64 & 9.27 & 15.15 & 10.175 & 15.24 & 10.475 & 17.285 & 9.23 & $\begin{array}{c}11.6 \\
35\end{array}$ & 9.53 & 1.22 \\
\hline MNHN-Bol-V 12545 & 17.83 & 11.45 & 9.86 & 9.1 & 11.28 & 11.7 & 18.61 & 12.35 & 19.54 & 12.72 & 20.31 & 11.54 & $\begin{array}{c}13.1 \\
5\end{array}$ & & \\
\hline $\begin{array}{l}\text { MNHN-Bol-V } 11999 \\
(=\mathrm{ACH} 355)\end{array}$ & & & & & 11.58 & 11.36 & 18.87 & 13.17 & 18.3 & 11.4 & 19.41 & 10.89 & & 7.68 & \\
\hline MNHN-Bol-V 12665 & 14.08 & 8.685 & 7.23 & 8.19 & 8.68 & 9.43 & 15.56 & 10.19 & 17.64 & 10.16 & 16.38 & 9.56 & $\begin{array}{c}10.5 \\
8\end{array}$ & & \\
\hline $\begin{array}{l}\text { MNHN Bol V12664 } \\
\text { MNHN-Bol-V } 11875\end{array}$ & 11.59 & 7.28 & 4.61 & 5.89 & 7.36 & 7.63 & 12.81 & 9.09 & 13.89 & 9.21 & & & & 8.79 & \\
\hline$(=\mathrm{GB} 228)$ & & & 6.815 & 7.72 & 8.385 & 9.12 & 15.33 & 10.12 & 16.015 & 10.41 & 16.51 & 9.31 & $\begin{array}{c}11 \\
12.2\end{array}$ & 9.07 & 1.21 \\
\hline MNHN-Bol-V 11676 & 17.81 & 11.6 & 6.85 & 9.41 & 8.8 & 9.54 & 18.32 & 10.54 & 17.31 & 11.08 & 18.545 & 10.405 & 4 & & \\
\hline
\end{tabular}

Table 3 Supplementary material 1. Upper teeth measurements of Plesiotypotherium achirense (in mm). For abbreviations see Figure 5 Supplementary material 1. 


\begin{tabular}{|c|c|c|c|c|c|c|}
\hline Number & L Mand & mo L & $\operatorname{den} L$ & d L & Co H & m2 H \\
\hline MNHN-Bol-V 12617 & 181.88 & 48.32 & 105.28 & 29.04 & 102.3 & \\
\hline MNHN-Bol-V 12663 & 164.35 & 43.46 & 90.82 & 20.79 & & 36.095 \\
\hline MNHN-Bol-V 3330 & 174.57 & 52.45 & 101.34 & 18.92 & 106.46 & 33.405 \\
\hline MNHN-Bol-V 12669 & 171.27 & 49.885 & 99.58 & 20.56 & 95.72 & 39.085 \\
\hline MNHN-Bol-V 9880 & 210.65 & 59.74 & & 24.79 & & 42.615 \\
\hline MNHN.F.ACH 20 & 174.78 & 46.525 & 96.205 & 22.71 & & 37.83 \\
\hline MNHN.F.ACH 26 (Holotype) & 188.985 & 51.805 & 106.9 & 24.475 & 98.16 & 40.8 \\
\hline MNHN.F.ACH 17 & 180.78 & 54.99 & & 21.1 & 107.88 & 41.96 \\
\hline MNHN.F.ACH 32 & & 54.98 & & & & 41.89 \\
\hline
\end{tabular}

Table 4 Supplementary material 1. Mandible measurements (in $\mathrm{mm}$ ) of Plesiotypotherium achirense. For abbreviations see Figure 5 Supplementary material 1. 


\begin{tabular}{|c|c|c|c|c|c|c|c|c|c|c|c|c|}
\hline Number & i1 mdl & i1blw & i2 $\mathrm{mdl}$ & i2 blw & P4mld & p4blw & m1mld & m1blw & m2mld & m2blw & m3 MLD & m3 BLW \\
\hline MNHN-Bol-V 12617 & 10.41 & 7.155 & 7.835 & 5.4 & 7.285 & 7.735 & & & & & 21.39 & 7.525 \\
\hline MNHN-Bol-V 12662 & 10.35 & 6.27 & & & 10.63 & 7.42 & 13.355 & 8.595 & 15.705 & 7.94 & 21.135 & 7.025 \\
\hline MNHN-Bol-V 12664 & & & & & 6.5 & 4.78 & 10.89 & 7.5 & 18.49 & 7.245 & & \\
\hline MNHN-Bol-V 12663 & 8.855 & 5.315 & 5.765 & 4.3 & 8.74 & 6.055 & 11.965 & 7.715 & 13.275 & 7.375 & 18.775 & 6.58 \\
\hline MNHN-Bol-V 12641 & & & & & 7.64 & 5.71 & & 5.35 & & & & \\
\hline MNHN-Bol-V 12670 & 10.76 & 6.61 & 7.52 & 4.7 & 11.9 & 7.77 & 13.97 & 9.57 & 15.69 & 9.67 & & \\
\hline MNHN-Bol-V 3330 & 10.99 & 6.655 & 5.15 & 4 & 10.38 & 6.75 & 13.955 & 8.33 & 16.045 & 7.22 & 19.28 & 7.1 \\
\hline MNHN-Bol-V 3334 & & & & & 11.66 & 6.92 & 13.55 & 8.45 & 14.81 & 7.63 & & \\
\hline MNHN-Bol-V 3755 & & & & & 9.79 & 7.12 & 11.7 & 8.23 & & & & \\
\hline MNHN-Bol-V 11677 & & & & & & & & & 13.24 & 8.04 & & \\
\hline MNHN-Bol-V 12669 & 10.03 & 6.555 & 7.085 & 5 & 9.925 & 7.975 & 13.685 & 9.785 & 15.52 & 9.63 & 22.11 & 8.16 \\
\hline MNHN-Bol-V 12670 & 10.76 & 6.61 & 7.52 & 4.7 & 11.9 & 7.77 & 13.97 & 9.57 & 15.69 & 9.67 & & \\
\hline MNHN-Bol-V 9880 & 12.11 & 7.47 & 8.44 & 4.9 & 11.935 & 8.385 & 16.23 & 10.09 & 17.23 & 9.53 & 23.64 & 9.37 \\
\hline MNHN-Bol-V 12642 & & & & & & & 13.08 & 7.85 & 12.22 & 7.24 & & \\
\hline MNHN.F.ACH 20 & 9.1 & 5.775 & 6.41 & 4.3 & 9.93 & 6.815 & 12.76 & 8.445 & 15 & 8.155 & 19.76 & 7.02 \\
\hline MNHN.F.ACH 26 & 10.655 & 6.45 & 7.215 & 5.1 & 11.315 & 7.89 & 13.78 & 9.55 & 15.485 & 9.03 & 22.265 & 8.19 \\
\hline MNHN.F.ACH 17 & & & & & 11.215 & 7.665 & 14.73 & 9.43 & 15.94 & 8.98 & 23.165 & 7.49 \\
\hline \multicolumn{13}{|l|}{ MNHN.F.ACH 30} \\
\hline MNHN.F.ACH 29 & 9.4 & 5.84 & 6.61 & 4.5 & 9.94 & 6.65 & 13.365 & 8.46 & 13.99 & 7.685 & 18.455 & 6.9 \\
\hline MNHN.F.ACH 36 & & & & & 12.26 & 8.69 & 15.59 & 9.97 & & & & \\
\hline
\end{tabular}

Table 5 Supplementary material 1. Lower teeth measurements (in mm) of Plesiotypotherium achirense. For abbreviations see Figure 5 Supplementary material 1. 


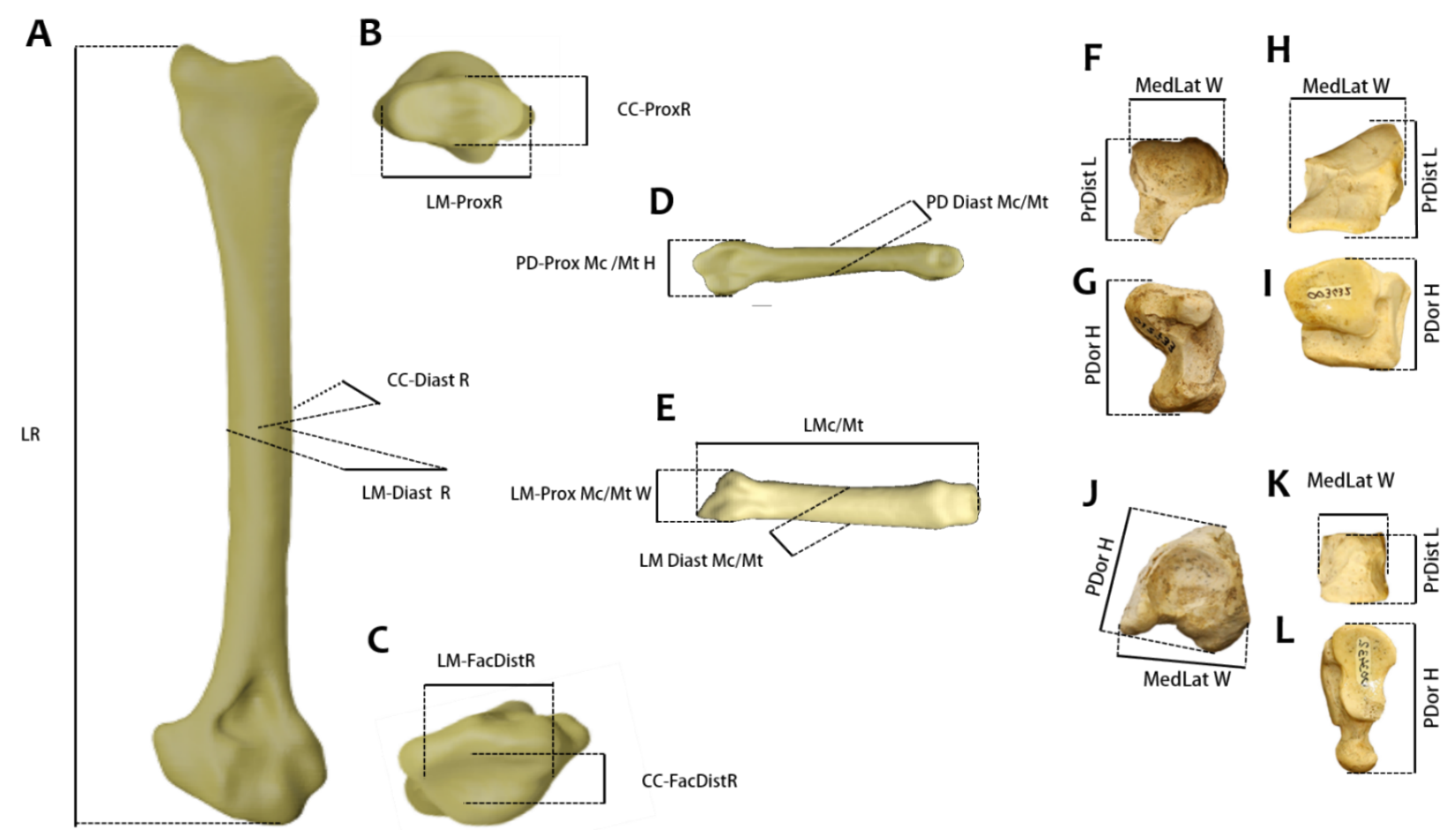

Table 6 Supplementary material 1. Measurements for postcranial elements (forelimb and hind limb). A-C. Radius measurements (a-c); Metacarpal or metatarsal measurements (d-e); Right scaphoid measurements in dorsal (f), and distal view (g); Left cuboid measurements in dorsal (H) and in distal view (i); Left navicular measurements in dorsal (h), and in proximal view (i); Left ectocuneiform measurements in dorsal (l), and in distal view (m). 


\begin{tabular}{ll} 
Abbreviated measurement & Description for the measurement \\
\hline LR & Radious length \\
CC-Diast R & Craniocaudal width of radius diaphysis \\
LM-Diast R & Lateromedial width of the radius diaphysis \\
CC-Prox R & Craniocaudal width of the radius head \\
LM-Prox R & Lateromedial width of the radius head \\
CC-Fac Dist R & Craniocaudal width of the fossa carpi radialis of radius \\
LM-Fac Dist R & Lateromedial width of the fossa carpi radialis of radius \\
LMc/Mt & Length of the Mc or Mt \\
LM-Prox W & Lateromedial width of the proximal epiphysis of the Mc or Mt \\
PD-Prox H & Plantodorsal width of the proximal epiphysis of the Mc or Mt \\
LM Diast Mc/Mt & Lateromedial width of the diastema of the Mc or Mt \\
PD-Diast Mc/Mt & Plantodorsal width of the diastema of the Mc or Mt \\
PrDist L & Proximodistal lenght (carpal or tarsal) \\
Med Lat W & Mediolateral width (carpal or tarsal) \\
P Dor H & Palmodorsal or plantodorsal height (carpal or tarsal) \\
\hline
\end{tabular}

Table 7 Supplementary material 1. Abbreviation, description and summary of postcranial measurements (in mm) of Plesiotypotherium achirense.

\begin{tabular}{|c|c|c|c|c|c|c|c|c|}
\hline Number & Element & LR & $\begin{array}{l}\text { CC- } \\
\text { Diast R }\end{array}$ & $\begin{array}{l}\text { LM- } \\
\text { Diast R }\end{array}$ & $\begin{array}{l}\text { CC-Prox } \\
\mathbf{R}\end{array}$ & $\begin{array}{l}\text { LM- } \\
\text { Prox R }\end{array}$ & $\begin{array}{l}\text { CC-Fac } \\
\text { Dist R }\end{array}$ & $\begin{array}{l}\text { LM-Fac } \\
\text { Dist R }\end{array}$ \\
\hline MNHN-Bol-V 12617 & Radius (R) & 141.38 & 10.4 & 27.20 & 15.59 & 27.24 & 15.85 & 22.38 \\
\hline MNHN-Bol-V 12617 & Radius (L) & 142.08 & 10.6 & 27.34 & 15.11 & 27.34 & 14.5 & 21.08 \\
\hline MNHN-Bol-V 12760 & Radius (R) & 148.5 & 10.98 & & 15.72 & 15.6 & 21.35 & 26.02 \\
\hline MNHN.F.ACH 18 (Paratype) & Radius & 170.64 & 13.4 & & 21.76 & 28.08 & 15.3 & 16.72 \\
\hline
\end{tabular}

Table 8 Supplementary material 1. Radius measurements (in $\mathrm{mm}$ ). For abbreviations see Table 7 Supplementary material 1. 


\begin{tabular}{|c|c|c|c|c|c|c|}
\hline Number & Element & $\mathbf{L M c} / \mathbf{M t}$ & $\begin{array}{l}\text { LM-Prox } \\
\text { Mc/Mt W }\end{array}$ & $\begin{array}{c}\text { PD-Prox Mc/Mt } \\
\text { H }\end{array}$ & $\begin{array}{c}\text { LM Diast } \\
\text { Mc/Mt }\end{array}$ & $\begin{array}{c}\text { PD-Diast } \\
\text { Mc/Mt }\end{array}$ \\
\hline MNHN-Bol-V 12617 & Mc V (R) & 49.74 & 8.82 & 13.58 & 5.53 & 7.9 \\
\hline MNHN.F.ACH 34 & Mc V (L) & 54.89 & 9.19 & 13.78 & 7.76 & 5.73 \\
\hline MNHN-Bol-V 12617 & Mc IV (L) & 60.92 & 17.62 & 14.62 & 8.6 & 9 \\
\hline MNHN-Bol-V 3440 & Mc IV (R) & & 18.4 & 16.1 & 10.4 & 8.9 \\
\hline MNHN-Bol-V 12617 & Mt III (L) & & 13.82 & 20.99 & 9.17 & 7.73 \\
\hline MNHN.F.ACH 26 (Holotype) & Mt III (R) & 57.39 & 12.77 & 20.21 & 9.99 & 7.8 \\
\hline MNHN-Bol-V 3336 & Mt III (R) & 59.58 & 13.09 & 19.94 & 9.83 & 8.3 \\
\hline MNHN-Bol-V 3738 & Mt III (R) & 57.2 & 15.3 & & & \\
\hline MNHN-Bol-V 3438 & Mt III (L) & & 16 & 21.7 & 12.9 & 9 \\
\hline MNHN-Bol-V 12617 & Mt V (L) & 46.51 & 9.44 & 14.45 & 6.15 & 6.09 \\
\hline MNHN-Bol-V 12650 & Mt V (R) & 50.9 & 11.2 & 17.2 & 7.4 & 6.14 \\
\hline MNHN-Bol-V 3740 & $\mathrm{Mc} V(\mathrm{R})$ & 59.9 & 11.1 & 17.3 & 9.82 & 7.36 \\
\hline
\end{tabular}

Table 8 Supplementary material 1. Measurements of the Mc or Mt. For abbreviations see Table 7 Supplementary material 1. 


\section{Ar/39Ar dating}

Samples were crushed and sieved and a 100-200 $\mu \mathrm{m}$ grain size was retained for feldspar separation. After magnetic separation, feldspar grains were selected under a stereomicroscope. The grains were leached with HNO3 $(1 \mathrm{~N})$ for a few minutes and then repeatedly cleaned ultrasonically in distilled water and alcohol. Samples were packed in aluminium foil for irradiation in the core of the Triga Mark II nuclear reactor of Pavia (Italy) with several aliquots of the Taylor Creek sanidine standard $(28.619 \pm 0.034 \mathrm{Ma}$ in Renne et al., 2011) as flux monitor. Argon isotopic interferences on $\mathrm{K}$ and $\mathrm{Ca}$ were determined by irradiation of $\mathrm{KF}$ and $\mathrm{CaF}_{2}$ pure salts from which the following correction factors were obtained: $\left({ }^{40} \mathrm{Ar} /{ }^{39} \mathrm{Ar}\right) \mathrm{K}=0.00969 \pm 0.00038,\left({ }^{38} \mathrm{Ar} /{ }^{39} \mathrm{Ar}\right) \mathrm{K}=0.01297 \pm 0.00045$, $\left({ }^{39} \mathrm{Ar} /{ }^{37} \mathrm{Ar}\right) \mathrm{Ca}=0.0007474 \pm 0.000021$ and $\left({ }^{36} \mathrm{Ar} /{ }^{37} \mathrm{Ar}\right) \mathrm{Ca}=0.000288 \pm 0.000016 .{ }^{40} \mathrm{Ar} /{ }^{39} \mathrm{Ar}$ step-heating analyses were performed at Géosciences Montpellier (France). The gas extraction and purification line consist of (a) an IR- $\mathrm{CO}_{2}$ laser of $100 \mathrm{kHz}$ used at $3-20 \%$ power to heat samples during 60 seconds, (b) a lenses system for beam focusing, (c) a steel chamber maintained at $10^{-8}-10^{-9} \mathrm{bar}$, with a copper holder in which $2 \mathrm{~mm}$-diameter blind holes were milled, and (d) two Zr-Al getters for purification of gases. Argon isotopes are analysed with an Argus VI multi-collection mass spectrometre (with 4 faradays for masses ${ }^{40} \mathrm{Ar}-{ }^{37} \mathrm{Ar}$ and ion counting on ${ }^{36} \mathrm{Ar}$ ). One minute was allowed for equilibration before analysis. Mass discrimination of machines is followed daily. Mass discrimination was monitored daily using an automated air pipette and provided a mean value of $0.99985 \pm$ 0.00274 per dalton. Micropopulations of feldspar crystals were distributed in holes of the copper holder and were step heated. Blank analyses were performed every three sample analyses. Raw data of each step and blank were processed and ages were calculated using the ArArCALC-software (Koppers, 2002). Isotopic ratios were corrected for irradiation interferences and air contamination using a mean air value $\left.\left({ }^{40} \mathrm{Ar} /{ }^{36} \mathrm{Ar}\right)\right)_{\mathrm{atm}}$ of $298.56 \pm 0.31$ 
(Lee et al., 2006; Renne et al., 2009). Ages are statistically analysed in two ways: ${ }^{39} \mathrm{Ar}$ released spectra and inverse isochrones. Plateau ages are calculated from at least three consecutive ${ }^{39} \mathrm{Ar}$ release steps comprising up to $50 \%$ of total ${ }^{39} \mathrm{Ar}_{\mathrm{K}}$ released and overlapping at the $2 \sigma$ confidence level (Fleck et al., 1977). Isochrone ages are accepted when mean square weighted deviation (MSWD) is close to 1 and the ${ }^{40} \mathrm{Ar} /{ }^{36} \mathrm{Ar}$ intercept within $2 \sigma$ from the $\left({ }^{40} \mathrm{Ar} /{ }^{36} \mathrm{Ar}\right)$ atm value. The analytical data are reported in the tables ACH TUF 4A A9.detailed.xls, ACH TUF 3A A10 plateau.detailed.xls and ACH TUF 3A A10 isochrone.detailed.xls. All errors are quoted at the $2 \sigma$ level uncertainty including the error on the irradiation factor $\mathrm{J}$.

Fleck, R.J., J. F. Sutter, and D. H. Elliot. 1977. Interpretation of discordant 40Ar/39Ar agespectra of mesozoic tholeiites from Antarctica: Geochimica et Cosmochimica Acta 41: $15-32$.

Lee J-Y, K. Marti, J. P. Severinghaus, K. Kawamura, H. S. Yoo, J. B. Lee, and J. S. Kim. 2006. A redetermination of the isotopic abundances of atmospheric Ar: Geochimica et Cosmochimica Acta 70:4507-4512.

Renne, P.R., G. Balco, K. R. Ludwig, R. Mundil, and K. Min. 2011. Response to the comment by W.H. Schwarz et al. on "Joint determination of 40K decay constants and 40Ar*/40K for the Fish Canyon sanidine standard, and improved accuracy for 40Ar/39Ar geochronology” by P.R. Renne et al. (2010): Geochimica et Cosmochimica Acta 75:5097-5100.

Renne, P.R., W. S. Cassata, and L. E. Morgan. 2009. The isotopic composition of atmospheric argon and 40Ar/39Ar geochronology: time for a change: Quaternary Geochronology $4: 288-298$. 